Research Article

\title{
Life Cycle Assessment (LCA) of Wood Flour and Pellets for Manufacturing Wood-Plastic Composites (WPCs)
}

Geeta Pokhrel ${ }^{1,+, \neq, *}$, Hongmei Gu ${ }^{2,+}$, Douglas J. Gardner ${ }^{1,3,{ }^{\dagger}}$, Shane O'Neill ${ }^{1,+}$

1. University of Maine, 5755 Nutting Hall, Orono, Maine, USA; E-Mails: geeta.pokhrel@maine.edu; douglasg@maine.edu; shane.r.oneill@maine.edu

2. US Forest Products Laboratory, One Gifford Pinchot Drive, Madison, Wisconsin, USA; E-Mail: hongmei.gu@usda.gov

3. University of Maine, 35 Flagstaff Road, Orono, Maine, USA

¥ Current Affiliation: Purdue University, 701 W Stadium Ave, West Lafayette, Indiana, USA; E-Mail: gpokhrel@purdue.edu

$\dagger$ These authors contributed equally to this work.

* Correspondence: Geeta Pokhrel; E-Mails: geeta.pokhrel@maine.edu; gpokhrel@purdue.edu

Academic Editor: Hossein Hosseinkhani

Special Issue: Life-cycle Analysis of Wood Building Materials and Bioenergy Resources for the Circular Economy

Recent Progress in Materials

2022, volume 4, issue 1

doi:10.21926/rpm.2201003
Received: December 07, 2021

Accepted: January 26, 2022

Published: February 09, 2022

\section{Abstract}

This study is expanding the previous studies that were focused on the material properties and transportation costs of the two alternative feedstocks for manufacturing wood-plastic composites (WPCs): wood flour and pellets. Besides the material properties and cost analysis, life-cycle assessment (LCA) is equally important to assess the environmental impacts of these two alternative wood feedstocks to manufacture WPCs and gain the knowledge of influences from the manufacturing and transportation processes. The main goal of this study was to compare the environmental impacts from the production and transportation of wood flour and pellets utilized in WPC manufacture. The environmental impacts on air, water, soil and

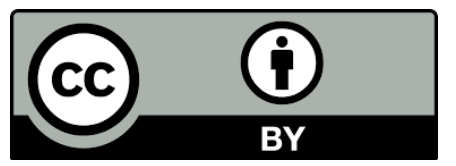

(C) 2022 by the author. This is an open access article distributed under the conditions of the Creative Commons by Attribution License, which permits unrestricted use, distribution, and reproduction in any medium or format, provided the original work is correctly cited. 
human health, as well as the cumulated energy consumption for one tonne and one truckload of the two wood feedstocks were compared. The case-study was based on a commercial wood pellet manufacturer in the state of Maine (ME). The cradle-to-gate approach was considered including the processing of mill residues, manufacturing of the two feedstocks and transporting them to commercial WPC manufacturers. LCA analysis showed that transportation of both feedstocks had the highest impact on the environment as opposed to the inputs associated with production. The global warming potential (GWP) from one tonne production and shipment of wood flour was higher by $8 \%$ compared to the pellets. One tonne production and shipment of wood pellets appears more environmentally friendly. Normalization results of one truck load of wood flour (22 tonnes) and pellets (30 tonnes) showed similar environmental impacts. Based on this study, from an environmental perspective, it is inferred that besides use as bio-fuels, wood pellets could be a better alternative feedstock for the manufacture of WPCs.

\section{Keywords}

Wood flour; wood pellets; wood-plastic composites (WPCs); life-cycle assessment (LCA); cumulative energy demand (CED)

\section{Introduction}

Wood and wood-based products are among the most important resources for sustainability. In the United States, wood and wood-based fuels contributed to around $20 \%$ for the production and consumption of renewable energy sources in 2017 [1]. Renewable energy is prominent in the transportation, electricity, and heating sectors with greater demand for wood fuels [2]. By 2030, attributable to the higher demand, there is increasing concerns on the scarcity of wood $[3,4]$. Thus, efficient utilization of forest resources is essential. Cascading principles drive the end-of-life (EoL) alternatives to prioritize alternative applications for wastes or waste management through prevention, re-use, recycling, recovery, and disposal. The circular economy is the other concept for the recycling and circulation of waste materials highlighted in the European Union (EU) $[5,6]$ as well as ProgRess in Germany [7] to minimize the use of virgin materials. EU has a target of recycling plastics and wood up to $50 \%$ and $25 \%$, respectively by 2025 and up to $55 \%$ and $30 \%$ by 2030 [8].

Life-cycle assessment (LCA) quantifies the inputs (i.e., materials and energy) and outputs (i.e., waste gases, wastewater, and solids) of a product/system and evaluates environmental impacts from each life cycle stage [9-16]. LCA is a tool to measure sustainability. The impacts of "cradle-tograve" or "cradle-to-cradle" ranging from acquisition of raw materials, processing, consumption, and transportation to final disposal of a product are analyzed [17]. Shifting among life cycle stages without hurdles, identifying major "hot spots" in the life cycle, and accounting the consequences to environment are the merits of LCA [18]. The International Organization for Standardization (ISO) 14040 [19] and ISO 14044 [20] are the major standards for this study. Results of LCA have greater implications for decision making [21], waste management [22], materials technologies [23], design and processing [24], and industrial ecology [25]. Similarly, the cumulative energy demand (CED) 
method assesses the direct and indirect energy usage in all life cycle stages of a product. It analyzes the renewable energy (RE) and non-renewable energy (NRE) consumption.

Secondary processing of mill residues generated after wood products manufacturing has various applications with low carbon emissions and less impact on forests [26]. One of the promising applications of mill residues is for raw material production in manufacturing wood-plastic composites (WPCs). WPCs are bio-based composites with applications in building materials [27, 28], automotive interior parts [29], and other consumer products. WPCs efficiently utilize biomass compared to recovering it for energy purposes [30]. WPCs are more environmentally friendly compared to pure plastics but can be less environmentally friendly than natural wood. Composites from recycled plastics can have more environmental benefits than from virgin sources [31]. Additives used in WPCs [32] and petroleum-based polymers such as polyethylene (PE), polypropylene (PP), polyvinyl chloride (PVC), etc. [18] can have deleterious effects on humans and their surroundings. Wood fiber reinforced polymers exhibit the most desirable performance over other natural fibers. While wood fiber fillers can increase the weight of automotive composites, they can still lead to sustainability [33]. The environmental impacts of pure PP products were found to be more severe than wood flour - PP composites [17].

Literature on comparative LCA of WPCs using various raw materials (wood, fiberglass, etc.) and based on the recyclability of the raw materials (virgin versus recycled) are available [34]. Sommerhuber et al. [35] and Vantsi \& Karki [36] have suggested that WPCs made with recycled waste wood have lower environmental impacts compared to virgin wood. A similar case holds with the use of virgin versus recycled PP. Wood flour is commonly used in the commercial manufacture of WPCs and can be produced from mill residues. Pokhrel et al. [37] and Pokhrel et al. [38] have pointed out that besides wood flour, wood pellets can be an alternative wood feedstock to compound with plastics in WPC manufacture. Wood pellets (densified wood flour) were explored to reduce the shipping cost of raw materials over long distances. The authors focused on the material properties of the WPCs using wood flour and pellets separately in a PP matrix, both with and without additives. Pokhrel et al. [39] also discovered transportation of pellets with respect to wood flour, can be cost-effective by at least $25 \%$ in a truck and at least $69 \%$ in other transportation mediums having a higher weight limit.

This study is a companion analysis to understand the environmental effects during the production and transportation of wood flour versus pellets. Based on the material types, sizes, and management, there are several classifications of wood pellets [40]. Conversion of materials into pellets makes it convenient for collection, storage, and transportation. The global wood pellet market size in 2020 was US $\$ 5,324$ million and is projected to be US $\$ 8,095.4$ million by the end of 2026 [41]. Compared to 2019, the global production of pellets increased by $7 \%$ with the value of 19.3 million tonnes [42]. The highest market share is of wood pellets followed by plastic pellets [43, 44]. Koči [45] mentioned that the weight of the pellets has a notable impact on the environmental performance of this product. LCA analysis on the manufacturing of wood pellets is abundant. However, an LCA study on wood flour manufacture is not available in the literature.

It is equally important to focus on the sustainability of the products besides the economic and material properties. Thus, this study aims to perform a comparative LCA and CED analysis in the production and transportation processes of the two feedstocks i.e., wood flour and pellets. This is a cradle-to-gate analysis considering one tonne and one truckload of the feedstocks as the functional units for two separate LCA studies to compare the environmental impacts and energy consumption. 
The input variables considered during the analysis are based on a study region in Maine (ME), USA, and are taken from the actual wood mill visits. Accordingly, after modeling the input variables in SimaPro software, impact assessment (characterization) under the categories: ozone depletion, global warming, smog, acidification, eutrophication, carcinogenic, non-carcinogenic, respiratory effects, ecotoxicity, and fossil fuel depletion were applied for the equitable comparison. Normalization of the impact categories for one truck load of the feedstocks were compared. Similarly, from CED-LHV method, consumption of different renewable (biomass, water, and wind, solar, geothermal) and non-renewable (fossil, nuclear, and biomass) energy sources are compared.

\section{Materials and Methods}

\subsection{Case Study}

This study was carried out in the state of Maine (ME) in the Northeast (NE) region of the US. The state of Maine, being rich in forest resources has more than 100 sawmills and turning mills, which are the backbone of the state's economy [46]. The wood mills generate around 1.6 million tonnes of residues each year [47]. However, the closure of many paper mills, instability of biomass power plants and pellet mills, etc. have caused a great problem in the outlet of wood residues [48]. On the other hand, there is a wood-plastic composite (WPC) manufacturer in the state that currently sources its feedstock materials i.e., wood flour from out of state. With these compelling problems in a state full of resources, this study was motivated to find potential solutions to use these residues effectively and efficiently. Furthermore, this study can be a representative study for the NE region of the US.

\subsection{Goals and Scope of the Study}

As mentioned in the introduction section, this study is a companion analysis attempting to use wood pellets as an alternative feedstock in WPCs production. The goal of this study is to compare the potential environmental impacts of wood flour versus pellets during processing using the mill residues as well as shipping via a combination long-haul truck. The individual impact from the material inputs and processes for each feedstock on the environment is also presented. ISO 14040 [19] and ISO 14044 [20] were followed in this LCA analysis. The scope of this study is a "cradle-togate" comparative LCA analysis. The study covers the processes from acquiring the residues/raw materials (cradle) to the production of wood flour and wood pellets followed by the transportation of these feedstocks to the WPC manufacturers (gate). In addition to this, a comparative CED analysis is also carried out. The mill residues as byproducts to produce wood flour and pellets are not produced in the physical site of pellet plant. Thus, generation of mill residues, their transportation to the pellet plant, and utilization of the two feedstocks in WPCs manufacturing is outside the scope of this study. The target users of this study's output are researchers, practitioners, and the WPC industry. The LCA evaluation of wood flour and pellets can be used as an input for other comparative LCAs of WPCs manufacturing using different feedstocks. This is a case study based on the largest wood pellet producer and distributor in ME; the output of this study can be applied to the NE region of the US for representation. In the year 2020, $57 \%$ of the residues were green sawdust from sawmills and $43 \%$ from chips. For the chips, $71.0 \%$ and $73.4 \%$ were from sawmill operations for hardwood and softwood respectively. Pulpwood chipped offsite by the pellet plant was $29.0 \%$ and 
26.6\% for hardwoods and softwoods respectively [49]. An equal ratio of hardwood and softwood residues was used. However, performing the LCA analysis of WPC manufacturing using wood flour or pellets mixing with plastics and additives is beyond the scope of the study. One of the major reasons is because as of now, there is no commercial production of WPCs using wood pellets and only wood flour is utilized. Even so, LCA analysis of WPC manufacturing using these two different wood feedstocks is important for creating a more thorough understanding of the entire manufacturing process.

\subsection{Life Cycle Assessment (LCA) Comparative Analysis}

Besides production, the transportation process has a considerable negative impact on energy consumption [50] thus, we have included transportation of the wood feedstocks in this LCA boundary system to examine the associated impacts. The boundary system for the cradle-to-gate LCA includes three major stages, which are 1). acquiring raw materials with transportation to the manufacturing site, 2). the manufacturing of the products - wood flour and pellets [51], 3). transportation of the wood feedstocks to the WPC manufacturers. During the cradle-to-gate LCA analysis, the input and output datasets are convenient, concise, and appropriate as they are directly obtained from the manufacturers of the products $[52,53]$. The four interrelated steps of LCA i.e., goal and scope, inventory analysis, impact assessment, and interpretation based on ISO standards 14040 and 14044 are explained in this study.

\subsection{Functional Unit}

The functional units can provide a reference in connecting the inputs and outputs to be normalized in the LCA as well as reflecting the goal and scope [19]. To compare the potential environmental impacts of the production and transportation of wood flour and wood pellets, we defined the two functional units for two comparative analyses, one as the one tonne of the feedstock products and the other as the one truckload of the feedstock products. One truckload can hold 22 tonnes of wood flour or 30 tonnes of pellets based on the vehicle weight limit and truck size in our study region. One tonne of the feedstock material is essential in the LCA study to maintain the uniformity of the inputs. One truckload is chosen because the weight of each wood feedstock a truck trailer can carry is different attributable to the bulk density of each material and the capacity limit of one truck trailer.

\subsection{Unit Processes and System Boundary}

The unit processes and system boundary are shown in Figure 1. The plant manufactures premium quality wood pellets from a mixture of hardwoods and softwoods. The emissions from production and transportation of two wood feedstocks for the WPC are conveyed by dotted lines, which include generation of wood residues as byproducts from hardwood or softwood sawmill operation, manufacturing of the wood feedstocks and then transporting them to the manufacturing of WPCs manufacturers. The cumulative system boundary is shown within the solid line. 


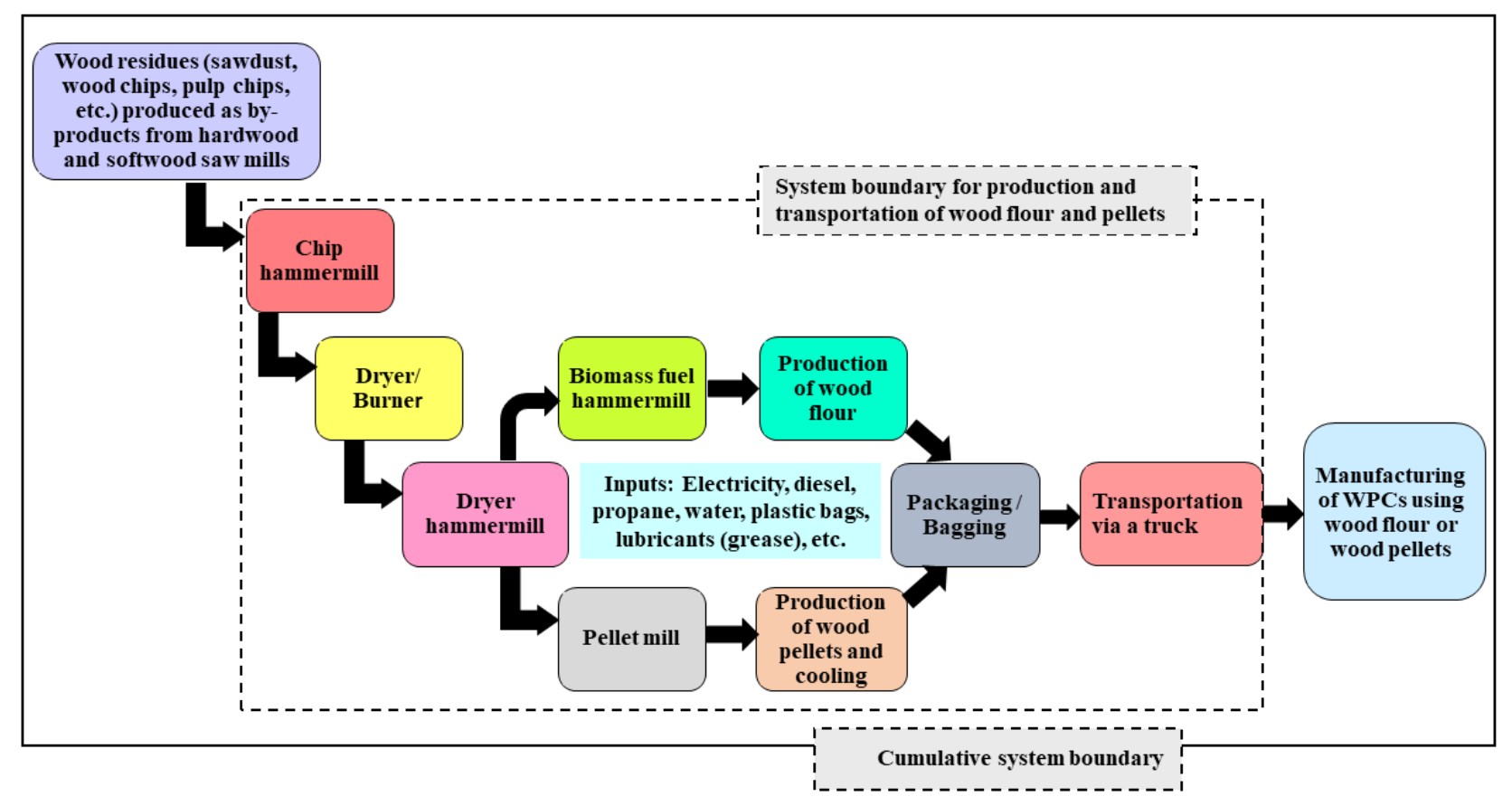

Figure 1 Unit processes and system boundary of the study.

a) Raw materials acquisition: The pellet mill used an equal proportion of hardwoods and softwoods residues acquired locally or from Canada, or the states in the New England region. The hardwoods used in the production consist primarily of maple and birch, with spruce-fir and hemlock as the primary softwoods. Cedar is excluded in pellet manufacture because of the considerable ash generation of the combusted product. Based on the average initial moisture content of $45-50 \%$ (wet basis) for residues by weight, two tonnes of residues are required to produce one tonne of pellets.

b) Chip hammer mill: Since most of the raw materials used were chips, the hammer mill for grinding the initial residues was termed as "chip hammer mill". There were five screens used in the chip hammermill with a screen size of $50.8-76.2 \mathrm{~mm}$. The capacity of this machine was $372.8 \mathrm{~kW}$.

c) Dryer/Burner: The ground materials from the chip hammermill were passed to the dryer or burner for the drying of residues. The average capacity of the dryer was 52,753 MJ which could dry the residues up to $7-10 \%$ of moisture content (wet basis). Less than one tonne of the residues $(0.74$ tonnes) was dried per hour. However, during winter, more heat energy is required for drying the freezing biomass. Propane is required for the burner in a dryer. $302.83 \mathrm{~L}$ of propane was consumed per day.

d) Dryer Hammermill: After drying, the residues are passed into the second hammermill termed as "dryer hammermill". The capacity of this machine was $372.8 \mathrm{~kW}$. There were four screens used with one side being $7.9 \mathrm{~mm}$ and the other side being $9.5 \mathrm{~mm}$ for each. Rollers were also used to ensure sawdust passed through the finer screen size. The classification of the screened feedstock from the output of dryer hammermill based on $7.9 \mathrm{~mm}$ round holes is given below:

$$
\begin{aligned}
& <4 \mathrm{~mm} \text { (5 mesh): } 99.31 \% \\
& <3.25 \mathrm{~mm} \text { ( } 6 \text { mesh): } 97.94 \% \\
& <2 \mathrm{~mm} \text { (10 mesh): } 83.16 \% \\
& <1 \mathrm{~mm} \text { (18 mesh): } 51.55 \% \\
& <0.1 \mathrm{~mm} \text { ( 140 mesh): } 4.12 \%
\end{aligned}
$$


e) Biomass fuel hammermill: This step is only for producing fine wood particles. In other words, what we have termed as "wood flour" in this study. In the manufacturing plant, the initial moisture content of the residues/biomass for the feed in this hammermill was slightly above 7\% which didn't change much even after grinding in the hammermill. There were two screens used with the size being $1.6 \mathrm{~mm}$. The machine capacity was $186.4 \mathrm{~kW}$ producing wood flour at the rate of 0.75 tonnes/hr. However, these obtained fine flour particles in the mills are not sold commercially that are reused in the biomass dryer for heating purposes.

f) Pelletizing: This step is only applicable for wood pellets, not flour. There were four pellet mills in the plant with the capacity of each $298.3 \mathrm{~kW}$ and a total of $1193.1 \mathrm{~kW}$ running through electric motors. The diameter of the die hole was $6.4 \mathrm{~mm}$. On average, the temperature of the pellet mill was $93-99^{\circ} \mathrm{C}$ and pressure of 207-483 MPa. No binding agent was used. Each pelletizer produces about 4.5 tonnes of pellets per hour. The moisture content of the pellets was 5-6\% (wet basis).

g) Cooling: Once pelletized, the pellets are very hot and are required to cool to the ambient temperature. A $0.19 \mathrm{~kW}$ cooler motor was used to cool the pellets in about 20 minutes for bagging or storage.

h) Packaging/Bagging: Pellets were fed by conveyor to the bagging station where the packaging robots running on electricity could pack the pellets. PE bags were used for bagging. They are packed into $18.14 \mathrm{~kg}$ plastic bags and 50 bags of these were packed together by another outer plastic cover. Each full stack of 50 bagged pellets contains one tonne of pellets. Similarly, silos used by the customers who desire bulk pellets delivery don't require any plastic bags. The plant had silos of 68 tonnes, 113 tonnes, 408 tonnes, and 32,658 tonnes. In comparison, wood flour is packed in super sacks or bulk bags in industries or as pellets shipped in silos that don't require packaging. The plastic bags for packaging flour are made up of PP with on average an accommodating capacity of $1.3 \mathrm{~m}^{3}$ volume and $0.45-4.81$ tonnes of weight.

i) Transportation via truck: The study also includes the environmental impacts during transportation besides processing. Forklift trucks were used to transfer the bagged materials to the truck for distribution of materials to consumers. Usually, a truck-trailer or combination trucks are used to ship forest-based products in the study region. Combination type trucks with long haul distance transport these wood feedstocks. The weight limit of the truck trailer is 33 tonnes with volume ranging from $98-114 \mathrm{~m}^{3}$. The calculation is based on one-way truck movement carrying the wood feedstock from the wood pellet mills to the consumers.

Throughout the manufacturing process, conveyors are used to transport the materials. Forklift, front-end loader, fire pumps, etc. use diesel for their operation. The mill has a biweekly shut down for cleaning, requiring 75.71 liters $(\mathrm{L})$ of water each time. The water could be well water or the water stored in a fire hydrant (851717.7 L). Similarly, lubricants (oil/grease) per pellet machine were purchased in barrels. Each pellet mill requires $0.35 \mathrm{~L}$ of oil/grease per hour. So, four pellet machines require $4 * 0.35 * 24=33.6 \mathrm{~L}$ per day and loaders require $29.6 \mathrm{~L}$ of oil/grease every four months. Likewise, for commercial wood flour production classification of wood flour before bagging/packaging is performed which is missing in our case study. During the mill visit, data were collected for each component of the pelletization process. Data were sourced from the weekly statistics collected in the manufacturing process under assessment. The electrical energy consumption data were also extracted from the annual data recorded in the plant in 2020 . The fine wood particles similar to the size of wood flour are produced by biomass fuel hammermills for the drying of biomass in the dryer. Thus, the initial steps for both wood flour and pellets production are 
the same which are separated when the grindings of dryer hammermill are used in pellet mill for making pellets and in biomass fuel hammer mill for wood flour production. Similarly, variation in transportation occurs attributable to a greater difference in the bulk density of the two materials in a truck having weight and volume limits.

\subsection{Life Cycle Inventory (LCI) of Material and Fuel Used}

The questionnaires related to the consumption of resources/fuels/materials from each unit process in the system boundary were prepared before the study. Data were collected by an onsite visit of the wood mill. The plant manager and other associated technical staff were interviewed. We were able to get the data we required for the LCA in this study. Likewise, secondary data from the literature were also referred to for more understanding. The collected data from the mill visit represents the 2020-21 production and transportation data. The wood mill was from ME in the NE region of the US, which is the largest manufacturer of wood pellets in the state with an annual production capacity of 90,718-99,790 tonnes of pellets or 318-363 tonnes of pellets per day. The plant operates 24 hours and 7 days a week. The pellet mill is not co-located with other wood product manufacturers. The plant doesn't sell wood flour; only sells wood pellets as its commercial product. Likewise, input values for transportation are also based on the actual survey data in the study region.

Sawdust, wood chips, and pulp chips were the sources for the two feedstock products in this study. Most of these are residues from local wood mills in the New England region or Canada. Thus, hardwood and softwood sawdust at the sawmill (green), hardwood and softwood wood chips at sawmill (green), and pulp chips at the sawmill were chosen as the primary material inputs. The summary of other LCl data sources along with the ancillary materials and energy used in the mill along with the transportation of the products is presented in Table 1. SimaPro 9.2.0.2 (PRé Consultants 2016) software was used to model the two feedstocks' manufacturing and shipping processes and evaluate the various environmental impacts based on the input variables. The database of USLCI and US-EI 2.2 (DATASMART package) was chosen to source the LCI datasets since they are based on the US manufacturing and electricity data. The DATASMART package is included in the SimaPro software. Data were chosen focusing on the US or if possible Northeast region of the US to closely represent regional impacts. Based on the collected values of the input variables, the models were developed in simulating the technical system as well as calculating the mass and energy flows within the system boundary. Life Cycle Impact Analysis ( $\mathrm{LCIA}$ ) method calculates the environmental loads for each unit process concerning the defined functional unit. 
Table 1 Input values of the LCA modeling for the production and transportation of one tonne of wood flour and pellets along with their $\mathrm{LCl}$ dataset chosen from the DATASMART in SimaPro.

\begin{tabular}{|c|c|c|}
\hline LCl Dataset & $\begin{array}{l}\text { Wood } \\
\text { flour }\end{array}$ & $\begin{array}{l}\text { Wood } \\
\text { pellets }\end{array}$ \\
\hline \multicolumn{3}{|l|}{ Input from nature (L) } \\
\hline Water, well, US (USLCI) & 0.02 & 0.02 \\
\hline \multicolumn{3}{|l|}{ Materials input (kg) } \\
\hline Sawdust, hardwood, green, at sawmill, NE-NC/kg/RNA (USLCI) & 285 & 285 \\
\hline Sawdust, softwood, green, at sawmill, NE-NC/kg/RNA (USLCI) & 285 & 285 \\
\hline Wood chips, hardwood, green, at sawmill, NE-NC/kg/RNA (USLCI) & 153 & 153 \\
\hline Wood chips, softwood, green, at sawmill NE-NC/kg/RNA (USLCI) & 158 & 158 \\
\hline Pulp chips, at sawmill, US SE/kg/US (USLCI) & 119 & 119 \\
\hline \multicolumn{3}{|l|}{ Fuel input (L) } \\
\hline Diesel, at refinery/I/US (USLCI) & 1.74 & 1.74 \\
\hline Liquefied petroleum gas, at refinery/I/US (USLCI) & 0.89 & 0.89 \\
\hline \multicolumn{3}{|l|}{ Electricity input (kWh) } \\
\hline Electricity, biomass, at power plant/US (USLCI) & 111.46 & 129.49 \\
\hline \multicolumn{3}{|l|}{ Transport input (tkm) } \\
\hline $\begin{array}{l}\text { Transport, combination truck, long-haul, diesel powered, } \\
\text { Northeast/tkm/RNA (USLCI) }\end{array}$ & 371 & 371 \\
\hline \multicolumn{3}{|l|}{ Ancillary inputs (kg) } \\
\hline Proxy_Oil and grease, at plant NREL/US U (US-EI 2.2) & 0.0007 & 0.09 \\
\hline Polypropylene, resin, at plant, CTR/kg/RNA (USLCI) & 10.28 & 0 \\
\hline Polyethylene, low density, resin, at plant, CTR/kg/RNA (USLCI) & 0 & 3.16 \\
\hline
\end{tabular}

\subsection{Life Cycle Impact Assessment (LCIA) and Cumulative Energy Demand (CED) Methodology}

The North American Tool for Reduction and Assessment of Chemicals and Other Environmental Impacts (TRACI) 2.1, US-Canadian 2008 method built-in SimaPro software was used for the environmental assessment [54]. The TRACI method is focused on the US and prepared by the US Environmental Protection Agency. It is a midpoint-oriented method. Besides the environmentrelated impacts, impacts to human health were also examined in the assessment process. $A$ total of 10 impact categories were reported from the TRACl method for both wood flour and pellets to compare in this study. These include ozone depletion (kg CFC-11-eq), global warming (kg $\mathrm{CO}_{2}$-eq), smog ( $\mathrm{kg} \mathrm{O}_{3}-\mathrm{eq}$ ), acidification ( $\mathrm{kg} \mathrm{SO}_{2}-\mathrm{eq}$ ), eutrophication ( $\mathrm{kg} \mathrm{N}$-eq), carcinogenic (CTUh), noncarcinogenic (CTUh), respiratory effects (kg PM2.5-eq), Ecotoxicity (CTUe), and fossil fuel depletion (MJ surplus). Likewise, the total primary energy input was quantified based on the LCI profiles and 
using the Single-issue method - CED (version 1.00 in SimaPro). The method is based on lower heating values (LHV) for the primary energy resources. Both the characterization and normalization results were compared for one truckload of each wood feedstock and each impact category. Characterization results display the actual values of each impact having different units whereas normalization calculates the magnitude of each impact on the same scale relative to the reference for a more equitable comparison. For one truckload of the various wood feedstocks, normalization of impact categories relative to the reference in SimaPro [55] as well as the lower heating values (LHV) were performed to examine if the variation in environmental impacts is caused by weight alone or the other variables as well. The LHV of wood flour in our case study is 19,502 $\mathrm{MJ} /$ tonne and wood pellets is $19,538 \mathrm{MJ} /$ tonne. Besides these factors, economic indicators could also be a basis for normalization but this is beyond the scope of the study.

\subsection{Assumptions}

a. There is no commercial production of wood flour in the studied wood mill as well as throughout the state of ME. The screen size used in the biomass fuel hammer mill was similar to the screen size used in wood flour production. Thus, grindings from the biomass fuel hammermill are comparable in sizing to wood flour, therefore were considered as "wood flour" for comparison with the wood pellets.

b. Wood flour is the major raw material in the manufacturing of WPCs commercially; there is no commercial application of wood pellets for WPCs manufacturing. However, as a follow-up to previous studies, we are assuming wood pellets can also be an alternative feedstock to WPCs.

c. All the unit operations in the pellet plant were single systems except the pellet mills which were four. Thus, the amount of electricity and other resources related to pellet mills is based on the average from the four pellet mills.

\subsection{Limitations}

The wood flour produced in this case study was not applied in WPCs manufacturing, instead was used as a feedstock for the biomass boiler/dryer. Thus, there are some limitations with the type of raw materials and processing steps as compared to the commercial wood flour production. Wood flour for manufacturing the WPCs is usually classified into different mesh/micron sizes after production by hammermill and before packaging or shipping. This case study has excluded the screening step because of the variation in the targeted end-use. Pulp chips are not typically chosen to make wood feedstock for manufacturing WPCs. However, the pellet mill in this study uses pulp chips as one of the residue types. Wood flour typically uses secondary residues that are already partially dried whereas pellet producers can use green as well as dried feedstocks. An additional drying process of the raw materials changes the LCA results in a large way [56]. Wood flour facilities are often co-located with the industries producing wood products that generate residues as their byproducts. Similarly, for large-scale production of WPCs, wood flour is never obtained in bags and for industrial wood pellets bags are also not used, but bags are commonly used for residential for ease of handling. Usually, pure hardwood or softwood species are used to make feedstocks for manufacturing WPCs. However, the pellet mill used a mixture of residues from hardwood and softwood species that need to be considered. These limitations can change the different impact categories of LCA as well as the consumption of energy sources and raw materials. Thus, future 
studies focusing on LCA analysis on commercial wood flour production to supply to the manufacturers are highly recommended. Furthermore, for a comparative LCA study between the two feedstocks, it is suggested to survey the facility where wood flour production for supplying to WPC manufacturers is co-located with the wood pellets production. Ensuring similar sources of raw materials, equipment, electricity, fuels, and the manufacturing setting is important in the comparative LCA study.

\section{Results and Discussion}

\subsection{Material Flows}

The values of the input variables considered in this study are presented in Table 1. As described in the methodology section, the production of both wood flour and pellets are similar starting from the same raw materials to the operation in drying hammermill. The production processes separate when the ground material from the dryer hammermill goes to the biomass fuel hammermill to produce wood flour whereas it goes to the pellet mill to make wood pellets. The major inputs consumed in the production of wood pellets are the wood residues and electricity [57] which applies to our case study as well. A similar situation holds for the wood flour which was clearly explained in section 2.5.

All the input values for the two feedstocks are similar except the quantity of plastic bags, lubricants, and electricity. Wood flour is normally packaged/bagged using PP whereas for pellets PE is used. PE bags have better flexibility, tear-resistance, and durability applicable for heavier items compared to PP bags [58]. That is why wood pellets being almost four times heavier than wood flour are packaged in PE bags and wood flour in PP bags. From an environmental point of view, both being thermoplastics are easier to recycle. However, for large-scale production of WPCs, the feedstocks are never bagged and silos are used that do not require plastic bags. Extra lubricating oil/grease was required for the pellet mills to make pellets. Similarly, variation in the equipment to produce wood flour i.e., hammermill, and for pellets i.e., pellet mill consumed different amounts of electricity. The average electricity used in the production of one tonne of wood flour by hammermill was $6 \mathrm{kWh}$ and wood pellets by pellet mills was $18 \mathrm{kWh}$. One tonne of bone-dried wood residues can produce one tonne of bone-dried wood flour or pellets (100\% yield) [57]. In our case study, the quantity of wood residues at $45-50 \%$ moisture content $(\mathrm{MC})$ required is almost double compared to the quantity of produced wood flour or pellets at 5-7\% MC. This suggests it is the weight of the moisture responsible for the heavier weight of the residues. Table 2 shows the values of heat energy of the dryer/boiler to reduce the $\mathrm{MC}$ and weight of the residues in the mill. All the $\mathrm{MC}$ (\%) values are based on a wet basis in this study. 
Table 2 Properties of residues in the dryer before and after drying. The heat energy required for drying the residues with the initial moisture content of $45 \%$ and $50 \%$ at different firing and thermal load rates are being presented. The data were obtained from the mill visit.

\begin{tabular}{|c|c|c|c|}
\hline $\begin{array}{l}\text { Properties of residues } \\
\text { before drying }\end{array}$ & $\begin{array}{l}\text { Properties of residues } \\
\text { after drying }\end{array}$ & $\begin{array}{l}\text { Firing rate (FR) and } \\
\text { thermal load (TL) } \\
\text { conditions }\end{array}$ & $\begin{array}{l}\text { Heat energy } \\
\text { (MJ/tonne } \\
\text { water removed) }\end{array}$ \\
\hline \multirow{4}{*}{$\begin{array}{l}\text { Weight of residues } 26.59 \\
\text { tonnes at a MC of } 45 \%\end{array}$} & \multirow{4}{*}{$\begin{array}{l}\text { Weight of water removed } \\
10.87 \text { tonnes, Weight of } \\
\text { dried residues } 15.73 \\
\text { tonnes at a MC of } 7 \%\end{array}$} & Low FR and low TL & 2427 \\
\hline & & Low FR and high TL & 2913 \\
\hline & & High FR and low TL & 2913 \\
\hline & & High FR and high TL & 3495 \\
\hline \multirow{4}{*}{$\begin{array}{l}\text { Weight of residues } 29.25 \\
\text { tonnes at a MC of } 50 \%\end{array}$} & \multirow{4}{*}{$\begin{array}{l}\text { Weight of water removed } \\
13.53 \text { tonnes, Weight of } \\
\text { dried residues } 15.73 \\
\text { tonnes at a MC of } 7 \%\end{array}$} & Low FR and low TL & 1950 \\
\hline & & Low FR and high TL & 2340 \\
\hline & & High FR and low TL & 2340 \\
\hline & & High FR and high TL & 2808 \\
\hline
\end{tabular}

\subsection{Impact Assessment of One Tonne Wood Flour and One Tonne Pellets}

The impacts from material and energy flows (wood residues, lubricants, electricity, diesel, propane, plastics, and transportation) in the production and shipping of one tonne of wood flour and pellets are shown in Figure 2 and Figure 3 respectively. The impacts calculated using the TRACI method are presented. The eutrophication impact is primarily caused by chemicals containing nitrogen or phosphorus into air or water, resulting nutrients runoff in an aquatic ecosystem and harm to biological productivity. Ecotoxicity is measured by the emission of heavy metals such as silver and barium into the water from the extraction process. Ozone depletion occurs with the release of chloromethane and bromomethane into the air during coal combustion. Sulfur oxides $\left(\mathrm{SO}_{\mathrm{x}}\right)$, nitrogen oxides $\left(\mathrm{NO}_{\mathrm{x}}\right)$, volatile organic compounds (VOCs), and particulate pollutants are the main sources of smog, acidification, and respiratory effects. Carbon dioxide $\left(\mathrm{CO}_{2}\right)$ emissions are separated by two sources, biogenic (biomass-derived) and anthropogenic (fossil fuel-derived). Biogenic $\mathrm{CO}_{2}$ may be considered carbon neutral as the $\mathrm{CO}_{2}$ emitted is reabsorbed during the growth of the tree and released on decomposition or burning of the tree. Although the $\mathrm{CO}_{2}$ emissions from the biomass combustion does not account for the GWP impact, the release of other components including $\mathrm{NO}_{\mathrm{x}}, \mathrm{SO}_{\mathrm{x}}$, and $\mathrm{VOCs}$ within biomass combustion have the most major contribution to the other environmental impacts. A detailed study on Global warming potential (GWP) will be discussed in section 3.5 below. 


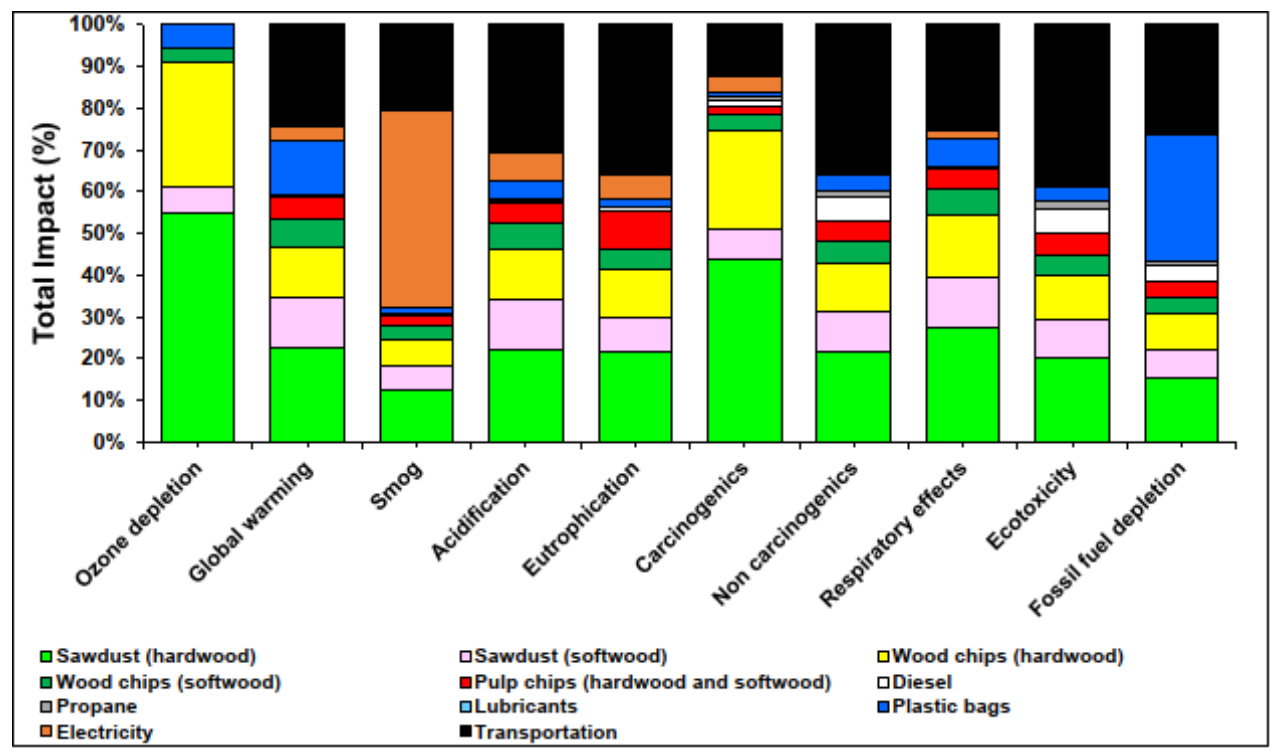

Figure 2 Impact assessment graph showing the relative contribution of the inputs for one tonne of wood flour.

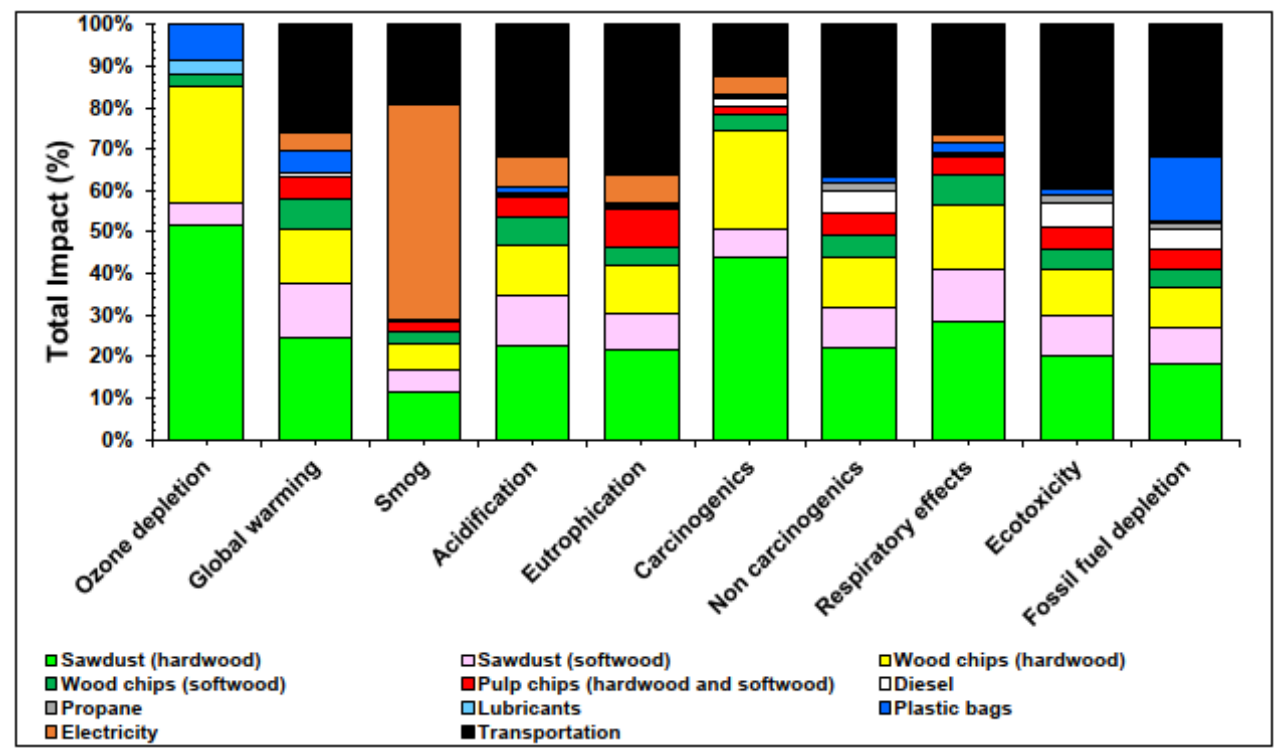

Figure 3 Impact assessment graph showing the relative contribution of the inputs for one tonne of wood pellets.

For both wood feedstocks, on average, the highest contribution to the different impact categories was observed mostly from transportation followed by the green sawdust produced at sawmills from hardwoods, and then from electricity. The use of diesel fuel in truck transportation intensifies greenhouse gas (GHG) emissions. Off-road transportation of the wood feedstock by trucks, front-end loader, forklifts, etc. consumed the most fuel i.e., diesel in a previous LCA study to produce softwood lumber [59]. Similarly, the hardwoods either as sawdust or chips had a higher negative impact on the environment as compared to the softwoods. Attributable to their much greater stiffness and density than softwoods, the hardwoods, in general, require more energy to harvest as well as mill process and the higher shipping costs. We used more sawdust than chips in this study which resulted in more impacts from sawdust than the chips. Previous studies [60,61] 
have shown differences in the energy consumption or environmental impacts between hardwood and softwood lumber manufacturing is attributable to the differences in the density of the wood species and regional electricity profiles. Briquetting logging residues for combined heating and power generation systems in the US have shown the electricity usage in preprocessing plants by far the greatest parameter for the overall GHG emissions [62], and the feedstock preparation stage had the largest share in global warming (GW) impact, mainly resulting from the drying process, followed by transportation [63]. Besides GHG emissions, the impact of wood processing steps was severe to the eutrophication attributable to electricity [64]. However, in our study, since Maine's electricity generation was dominated by biomass energy, the effect is less severe to the environment compared to some other inputs such as transportation and green sawdust from hardwoods.

The impact from transportation was the most severe to the global warming, acidification, eutrophication, noncarcinogenic, and ecotoxicity for both wood flour and pellets. The impact from electricity use was the highest for smog production. The green sawdust from hardwood contributes most to ozone depletion, carcinogenic, and respiratory effects. In a study of hybrid timber building, it was observed that on increasing the wood materials the influence on ozone depletion was the most and on global warming potential the least [65]. The effect of plastic bag use was also noticeable to the ozone depletion, global warming, and respiratory effects. The effect of diesel was mostly observed on non-carcinogenic, ecotoxicity, and fossil fuel depletion for both feedstocks. The prominent effect of lubricating oil/grease was ozone layer depletion. Likewise, the effect of propane was higher for noncarcinogenic, ecotoxicity, and fossil fuel depletion. The effect of pulp chips was most noticeable to eutrophication for either of the materials. Besides, the influence of sawdust and wood chips from softwoods were severe to global warming and plastic bags on fossil fuel depletion.

The impact of plastic bags was the most to fossil fuel depletion in the case of wood flour (Figure 2) whereas, for pellets, transportation had the most negative influence on fossil fuel depletion (Figure 3). This was attributable to the severe impact of PP compared to PE and for the same amount of the wood feedstock, the quantity of plastic bags required to bag the wood flour is higher than the pellets. For wood flour, after fossil fuel depletion, the major impact of plastic bags was on global warming whereas, for pellets, it was more on ozone depletion. Effect of lubricant was higher for wood pellets than flour as more lubricant was used in the four pellets mills. Meanwhile, an attributional LCA [40] conducted on the WPCs found the environmental impacts for the WPCs are lower because of the impacts from wood feedstocks attributable to the less fossil fuel consumption.

\subsection{Comparative Inventory Assessment}

Table 3 is the inventory of major emissions to the air, water, and soil generated from the production and shipping of the two feedstocks. Table 3 also lists the most influential emission sources. The input variables causing the maximum emissions were the same for wood flour or pellets except $\mathrm{SO}_{x}$ emissions. The major emissions to air were from hardwood sawdust and for water was transportation. The hardwood sawdust contributes either the most (highest impacting inputs) or the second in all the listed air emissions in Table 3. Emissions to air especially the VOCs from wood pellets depend on the drying temperature, raw materials nature, and self-heating of the pellets [66]. There was no impact from diesel, propane, lubricants, and electricity on $\mathrm{SO}_{\mathrm{x}}$ emissions for both wood feedstocks. COD and BOD5 were not impacted by the lubricants. Bark was only generated from pulp chips without the influence of other production or transportation inputs. 
Table 3 Emissions to air, water, and soil associated with the production and transportation of one tonne of wood flour and pellets from the mill residues. The most highly impacting inputs for each emission from both feedstocks are the same except $\mathrm{SO}_{\mathrm{x}}$ emissions.

\begin{tabular}{|c|c|c|c|c|c|}
\hline \multirow[t]{2}{*}{ Emissions } & \multicolumn{2}{|l|}{ Wood Flour } & \multicolumn{2}{|c|}{ Wood pellets } & \multirow{2}{*}{$\begin{array}{l}\text { Highest impacting } \\
\text { inputs }\end{array}$} \\
\hline & $\begin{array}{l}\text { Production } \\
(\mathrm{kg})\end{array}$ & $\begin{array}{l}\text { Transportation } \\
(\mathrm{kg})\end{array}$ & $\begin{array}{l}\text { Production } \\
(\mathrm{kg})\end{array}$ & $\begin{array}{l}\text { Transportation } \\
(\mathrm{kg})\end{array}$ & \\
\hline \multicolumn{6}{|l|}{ Emissions to air } \\
\hline a. $\mathrm{CO}_{2}$ (fossil) & 101.9 & 34.1 & 95.9 & 34.1 & Transportation \\
\hline b. $\mathrm{CO}_{2}$ (biogenic) & 105.97 & $2.75^{*} 10^{-2}$ & 166.97 & $2.75 * 10^{-2}$ & Electricity \\
\hline c. Acetaldehyde & $1.53 * 10^{-4}$ & $9.42 * 10^{-8}$ & $1.53 * 10^{-4}$ & $9.42 * 10^{-7}$ & Hardwood sawdust \\
\hline d. Acrolein & $2.42 * 10^{-4}$ & $1.01 * 10^{-7}$ & $2.42 * 10^{-4}$ & $1.01 * 10^{-7}$ & Hardwood sawdust \\
\hline e. Formaldehyde & $4.26 * 10^{-4}$ & $1.97 * 10^{-6}$ & $4.24 * 10^{-4}$ & $1.97 * 10^{-6}$ & Hardwood sawdust \\
\hline f. Phenol & $1.03 * 10^{-10}$ & $2.39 * 10^{-12}$ & $3.26 * 10^{-9}$ & $2.39 * 10^{-12}$ & Lubricants \\
\hline g. $\quad \mathrm{NO}_{\mathrm{x}}$ & 0.799 & 0.261 & 0.819 & 0.261 & Hardwood sawdust \\
\hline h. $\mathrm{SO}_{2}$ & 0.3385 & 0.0205 & 0.3155 & 0.0205 & Hardwood sawdust \\
\hline i. $\mathrm{SO}_{\mathrm{x}}$ & $1.54 * 10^{-2}$ & $2.12^{*} 10^{-7}$ & $7.86 * 10^{-3}$ & $2.12 * 10^{-7}$ & $\begin{array}{l}\text { Pellets-hardwood } \\
\text { sawdust, Flour-PP }\end{array}$ \\
\hline j. $\quad$ Methane & 0.1501 & $4.69 * 10^{-2}$ & 0.1481 & $4.69 * 10^{-2}$ & Hardwood sawdust \\
\hline $\begin{array}{l}\text { k. Particulates } \\
\text { (unspecified) }\end{array}$ & 0.741 & $3.51 * 10^{-3}$ & 0.742 & $3.51 * 10^{-3}$ & Hardwood sawdust \\
\hline $\begin{array}{l}\text { I. VOCs } \\
\text { (unspecified) }\end{array}$ & $3.03 * 10^{-2}$ & $1.61 * 10^{-2}$ & $2.51 * 10^{-2}$ & $1.61 * 10^{-2}$ & Transportation \\
\hline \multicolumn{6}{|l|}{ Emissions to water } \\
\hline $\begin{array}{l}\text { a. Biological } \\
\text { oxygen demand } \\
\text { (BOD5) }\end{array}$ & 0.1227 & $7.3^{*} 10^{-3}$ & 0.1217 & $7.3^{*} 10^{-3}$ & Hardwood sawdust \\
\hline $\begin{array}{l}\text { b. Suspended } \\
\text { soils }\end{array}$ & 3.18 & 1.88 & 3.1 & 1.88 & Transportation \\
\hline $\begin{array}{l}\text { c. Chemical } \\
\text { oxygen demand } \\
\text { (COD) }\end{array}$ & $2.4 * 10^{-2}$ & $1.39 * 10^{-2}$ & $2.29 * 10^{-2}$ & $1.39 * 10^{-2}$ & Transportation \\
\hline d. Chloride & 2.43 & 1.44 & 2.38 & 1.44 & Transportation \\
\hline Emissions to soil & & & & & \\
\hline a. Bark & 1.59 & 0 & 1.59 & 0 & Pulp chips \\
\hline
\end{tabular}

In the comparative inventory assessment of one tonne of each feedstock, the quantity $(\mathrm{kg})$ of emissions of bark, acetaldehyde, and acrolein were the same. Emissions of BOD, chloride, COD, suspended soils, (fossil), formaldehyde, methane, $\mathrm{SO}_{2}, \mathrm{SO}_{x}$, and $\mathrm{VOCs}$ were greater for one tonne of wood flour as compared to the one tonne of pellets. The rest of the emissions i.e., $\mathrm{CO}_{2}$ (biogenic), $\mathrm{NO}_{x}$, and particulates were greater for the wood pellets than the wood flour and were only air emissions. Likewise, in a comparative inventory assessment of one truckload of wood flour and pellets, the emissions to air, water, and soil as mentioned in Table 3 were higher for wood pellets 
compared to wood flour. However, the exception is with $\mathrm{SO}_{\mathrm{x}}$, which was greater for wood flour than the pellets. Similarly, the $\mathrm{CO}_{2}$ (fossil) emission was the same for both materials. Slightly, higher emissions to air, water, and soil in the production and transportation of one truckload of wood pellets (30 tonnes) compared to the wood flour (22 tonnes) are obvious as more tonnes of production and transportation consume more energy, materials, fuels, etc.

\subsection{Comparative Impact Assessment of the Two Feedstocks of Different Functional Units}

The impact assessment results for one tonne and one truckload of the two feedstocks are presented in Table 4. Values of each impact associated with the production and shipping of one tonne and one truckload of wood flour and pellets are compared along with the differences in percentages. The difference between the two feedstocks for different functional units are plotted in Figure 4 and Figure 5 for comparison. For one tonne production and transportation of the two feedstocks, wood flour presented higher impacts on the environment than the pellets for most categories except ozone depletion and smog (Table 4, Figure 4). There was no difference in the carcinogenic impacts between the two. The percentage differences ranged from $0-16.5 \%$ as shown in Table 4. The major input imparting greater influence on wood flour compared to pellets could be the plastic bags. Higher resource usage on their production and the larger waste generation induces plastics to have a huge effect on the environment [67]. Although the wood pellets production required more electrical energy than flour, the source being biomass for electricity generation, the impact is much reduced. And even though the application of the lubricant varies for flour and pellets, its quantity is much less to make noticeable differences.

Table 4 Environmental impacts associated with the production and transportation of one tonne or one truckload of wood flour and pellets.

\begin{tabular}{|c|c|c|c|c|c|c|c|}
\hline \multirow[t]{2}{*}{ Impact category } & \multirow[t]{2}{*}{ Unit } & \multicolumn{3}{|c|}{ Functional unit (one tonne) } & \multicolumn{3}{|c|}{ Functional unit (one truckload) } \\
\hline & & $\begin{array}{l}\text { Wood } \\
\text { flour }\end{array}$ & $\begin{array}{l}\text { Wood } \\
\text { pellets }\end{array}$ & $\begin{array}{l}\text { Difference } \\
\text { (\%) }\end{array}$ & $\begin{array}{l}\text { Wood } \\
\text { flour }\end{array}$ & $\begin{array}{l}\text { Wood } \\
\text { pellets }\end{array}$ & $\begin{array}{l}\text { Difference } \\
(\%)\end{array}$ \\
\hline Ozone depletion & $\begin{array}{l}\mathrm{kg} \text { CFC- } \\
11 \mathrm{eq}\end{array}$ & $1.98 * 10^{-6}$ & $2.12 * 10^{-6}$ & 6.5 & $4.35 * 10^{-5}$ & $6.35 * 10^{-5}$ & 31.5 \\
\hline Global warming & $\mathrm{kg} \mathrm{CO}{ }_{2} \mathrm{eq}$ & 146.33 & 135.20 & 7.6 & 3219.19 & 4055.87 & 20.6 \\
\hline Smog & $\mathrm{kg} \mathrm{O} \mathrm{O}_{3} \mathrm{eq}$ & 56.74 & 60.53 & 6.3 & 1248.25 & 1815.97 & 31.3 \\
\hline Acidification & $\mathrm{kg} \mathrm{SO}_{2} \mathrm{eq}$ & 1.47 & 1.44 & 2.1 & 32.31 & 43.13 & 25.1 \\
\hline Eutrophication & kg Neq & $7.63 * 10^{-2}$ & $7.60 * 10^{-2}$ & 0.3 & 1.68 & 2.28 & 26.4 \\
\hline Carcinogenics & CTUh & $4.30 * 10^{-6}$ & $4.29 * 10^{-6}$ & 0 & $9.45 * 10^{-5}$ & $1.29 * 10^{-4}$ & 26.6 \\
\hline Non carcinogenics & CTUh & $1.43^{*} 10^{-5}$ & $1.40 * 10^{-5}$ & 2.3 & $3.15^{*} 10^{-4}$ & $4.19 * 10^{-4}$ & 24.9 \\
\hline $\begin{array}{l}\text { Respiratory } \\
\text { effects }\end{array}$ & $\begin{array}{l}\mathrm{kg} \\
\mathrm{PM} 2.5 \mathrm{eq}\end{array}$ & $5.18 * 10^{-2}$ & $4.96 * 10^{-2}$ & 4.3 & 1.14 & 1.49 & 23.4 \\
\hline Ecotoxicity & CTUse & 256.08 & 250.69 & 2.1 & 5633.84 & 7520.82 & 25.1 \\
\hline $\begin{array}{l}\text { Fossil fuel } \\
\text { depletion }\end{array}$ & $\begin{array}{l}\text { MJ } \\
\text { surplus }\end{array}$ & 283.28 & 236.52 & 16.5 & 6232.07 & 7095.74 & 12.2 \\
\hline
\end{tabular}




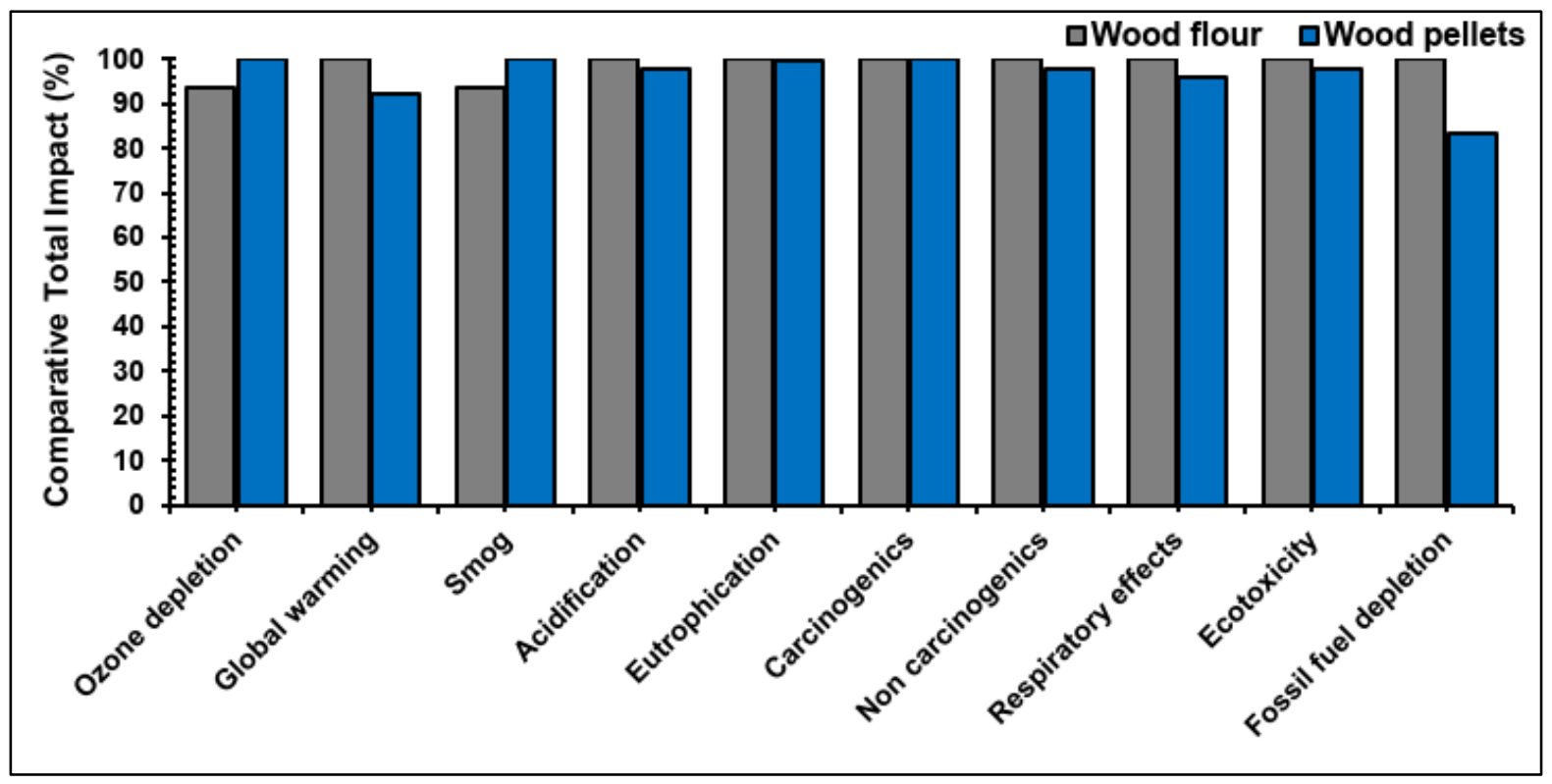

Figure 4 Comparative impact assessments for one tonne of wood flour and pellets.

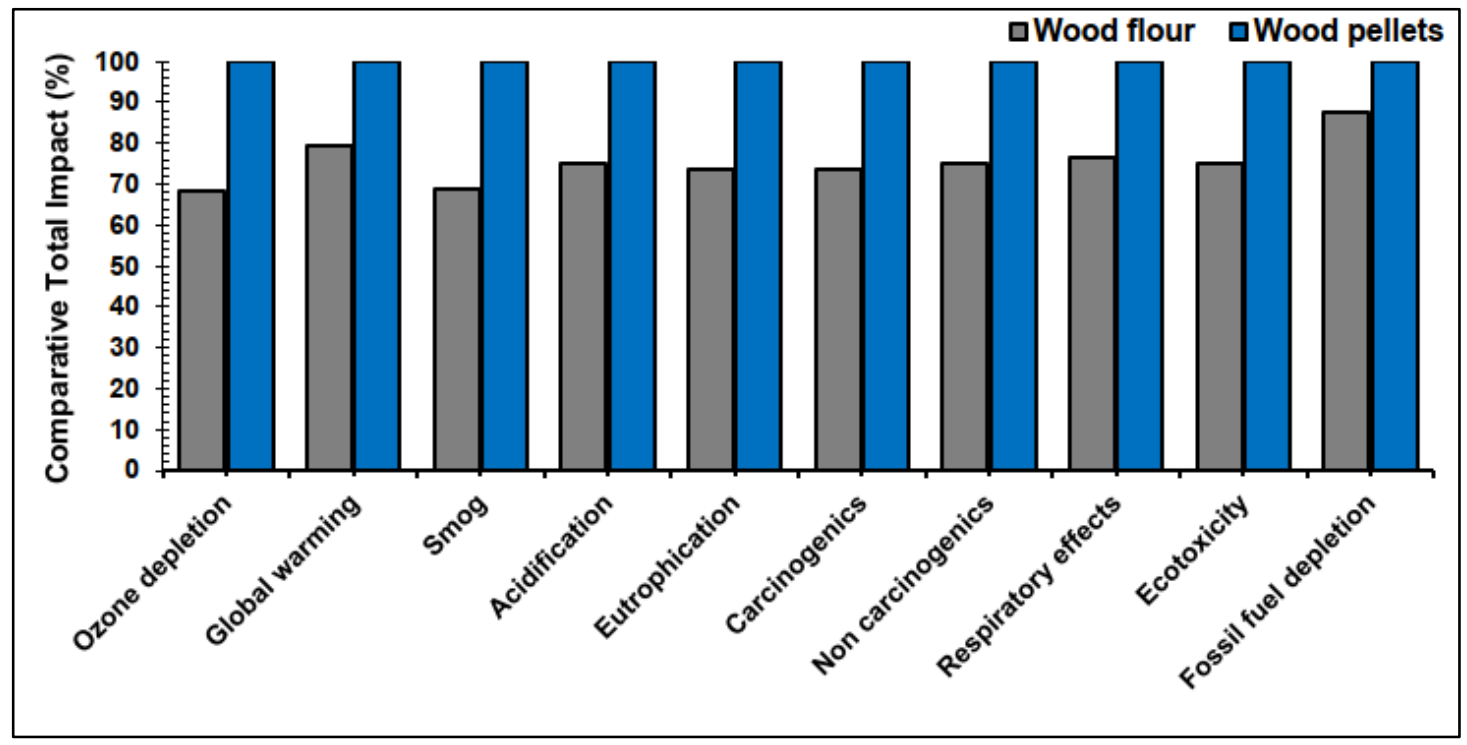

Figure 5 Comparative impact assessments for one truckload of wood flour and pellets.

For one truckload production and shipping of the two feedstocks, wood flour showed less impacts in all the categories (Table 4) in this study, primarily attributable to the mass difference in the one truckload shipment. Compared to the one truckload of wood pellets ( 30 tonnes), the impact on the environment from one truckload of wood flour (22 tonnes) was smaller for all impact categories (Figure 5). The differences in the impact ranged from $12-30 \%$ on average as shown in Table 4. Wood flour, in general, seems to have less impact on ozone depletion and smog compared to the pellets. However, their impacts on fossil fuel depletion and global warming are quite remarkable compared to the pellets. More tonnes of wood pellet production and transportation can have more environmental impacts when examined on the truckload functional unit. Still, the impacts are considerable for the wood pellets rather than flour for one truckload, with a difference of eight tonnes of production and shipping. However, this may not be in favor to the cost analysis. 


\subsection{Normalization of Impacts for One Truckload of the Feedstocks}

For one truckload of wood flour and pellets, normalization results as derived from the SimaPro outputs are shown in Figure 6. For each of the impact categories, the difference in normalization scale is quite low between the two feedstocks. The slightly higher difference is seen in the carcinogenics and smog with wood pellets contributing more than flour. Wood pellets, basically the ash can contain heavy metals (quantity depends on species) that may induce the carcinogenic effects [68]. However, the differences in the rest of normalizations for wood flour and pellets (one truckload) were notably low. Likewise, the results of characterization showing different units for each impact category creates difficulty in recognizing the major impact to the environment. Thus, with SimaPro's normalization of the impact values across the categories, it was observed that the major impact was on carcinogenics followed by smog and ecotoxicity and the least on ozone depletion. The effects on global warming, acidification, eutrophication, respiratory effects, and fossil fuel depletion were minor for each wood feedstock type. Since the major focus is on GWP, the contribution from wood flour or pellets is similar and in a lower scale range. Normalization scale in SimaPro is the average of all the LCA impact indicators across all industry sectors. Thus, this might not be representative of the wood products industry.

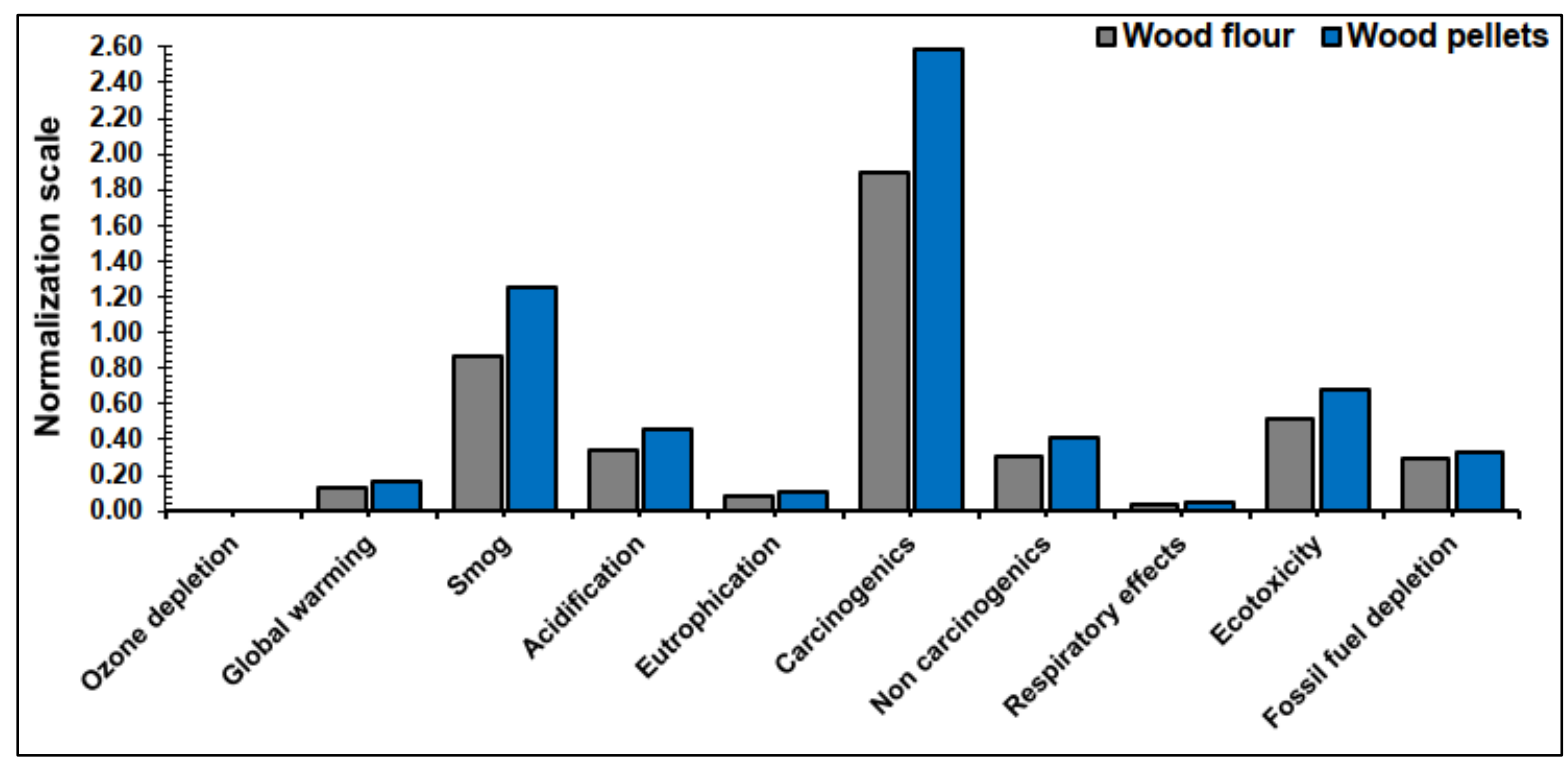

Figure 6 Comparative normalization based on SimaPro normalization factors.

In addition, normalization based on the LHV of the feedstocks indicated a negligible difference among the different impact categories for one truck load of both wood feedstocks (Table 5 and Figure 7). Heating values emphasize energy efficiency as well as analyzing the cost-effectiveness of a combined heat and power plant. LHV is related to the products of combustion containing water vapor and the heat in the water vapor not being recovered. The LHV-based normalization values are presented in Table 5 and the difference in percentage are shown in Figure 7. The values of different impacts are similar for one truckload of wood flour and pellets. GWP difference of $7.8 \%$ between the two feedstocks is observed. The variation in the resulting impacts to the different aspects of environment such as: air, water, and soil as well as human health were similar for one truckload production and transportation of wood flour and pellets. These results indicate that besides the 
difference in weight of the truckload of two feedstocks i.e., eight tonnes, the variation in the impacts for the truckload is also influenced by the total heating values of the feedstocks.

Table 5 Comparative normalization values for wood flour and pellets (one truckload) based on their LHV.

\begin{tabular}{llll}
\hline Impact categories & Wood flour & Wood pellets & Difference (\%) \\
\hline Ozone depletion & $1.0^{*} 10^{-10}$ & $1.1 * 10^{-10}$ & 6.4 \\
Global warming & $7.5 * 10^{-3}$ & $6.9 * 10^{-3}$ & 7.8 \\
Smog & $2.9 * 10^{-3}$ & $3.1 * 10^{-3}$ & 6.1 \\
Acidification & $7.5 * 10^{-5}$ & $7.4 * 10^{-5}$ & 2.3 \\
Eutrophication & $3.9 * 10^{-6}$ & $3.9 * 10^{-6}$ & 0.5 \\
Carcinogenics & $2.2 * 10^{-10}$ & $2.2 * 10^{-10}$ & 0.2 \\
Non carcinogenics & $7.3 * 10^{-10}$ & $7.2 * 10^{-10}$ & 2.5 \\
Respiratory effects & $2.7 * 10^{-6}$ & $2.5 * 10^{-6}$ & 4.5 \\
Ecotoxicity & $1.3 * 10^{-2}$ & $1.3 * 10^{-2}$ & 2.3 \\
Fossil fuel depletion & $1.5 * 10^{-2}$ & $1.2 * 10^{-2}$ & 16.7 \\
\hline
\end{tabular}

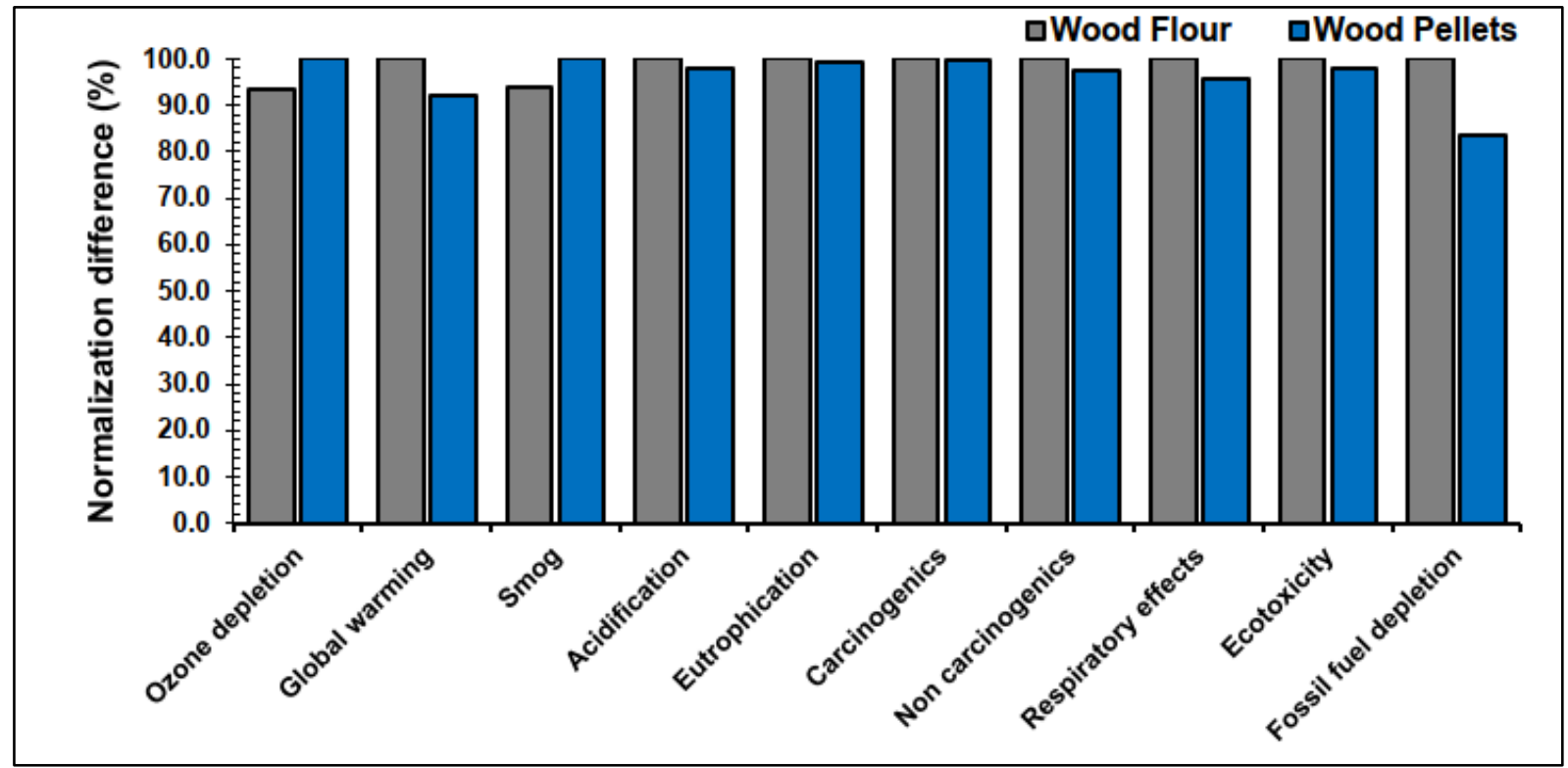

Figure 7 Comparative normalization based on the LHV of the wood feedstocks.

\subsection{Global Warming Potential (GWP)}

Out of several impact categories, the major focus is on the global warming potential (GWP) at present as it determines the future climatic conditions on earth and a basis for carbon pricing. The greenhouse gases (GHG) reduction strategies have been of keen interest as the earth's temperature is increasing. Carbon tracking is crucial for global policy making. $\mathrm{CO}_{2}$, methane, and $\mathrm{NO}_{\mathrm{x}}$ are the major contributing gases for the 100-year global warmings [62]. The production and shipment of one tonne of wood flour emitted a greater amount of $\mathrm{CO}_{2}$, methane, and $\mathrm{NO}_{x}$ compared to the pellets in this study. Similarly, the emission of these gases was higher for 30 tonnes (one truckload) of wood pellets (by $21 \%$ ) than 22 tonnes (one truckload) of wood flour. In addition to this, the initial 
moisture content of the mill residues is elevated (45-50\% on a wet basis) in the selected pellet plant. The moisture content of the feedstock is vital as this is responsible for global warming impacts as well as costs attributable to the application of propane in drying [69]. The authors recommend air drying of the high moisture containing residues to lower the ecological and economical burdens. Similarly, Alanya et al. [64] in their study on the wood pellet sector in the US mentioned the supply of raw materials and the manufacturing stages contributed most to different impacts categories. During manufacturing, the most influence on GHG emissions was through electricity consumption in wood processing processes. After manufacturing, raw materials transportation had a vital role in the GWP. The authors reported an increase in transportation distance from a minimum of $250 \mathrm{~km}$ to a maximum of $1250 \mathrm{~km}$ results in a $35 \%$ increase in the total GW impact.

\subsection{Cumulative Energy Demand (CED)}

With the CED single-issue method output from the SimaPro LCA model, the different renewable and non-renewable energy consumed for manufacturing and hauling of one tonne or one truckload of the wood feedstocks are summarized in Table 6 . The percentage difference between the two feedstocks in the amount of renewable energy (RE) and non-renewable energy (NRE) consumed for each functional unit (one tonne or one truckload) are shown in Figure 8a and Figure 8b, respectively.

Table 6 Renewable and non-renewable energy consumed during one tonne and one truckload production to transportation of the two wood feedstocks.

\begin{tabular}{|c|c|c|c|c|}
\hline \multirow[b]{2}{*}{ Impact category } & \multicolumn{2}{|c|}{ Functional unit (one tonne) } & \multicolumn{2}{|c|}{ Functional unit (one truckload) } \\
\hline & Wood flour & $\begin{array}{l}\text { Wood } \\
\text { pellets }\end{array}$ & Wood flour & $\begin{array}{l}\text { Wood } \\
\text { pellets }\end{array}$ \\
\hline Non-renewable, fossil (MJ) & 2310 & 2009 & 50825 & 60274 \\
\hline Non-renewable, nuclear (MJ) & 0.12 & 0.30 & 2.65 & 8.87 \\
\hline Non-renewable, biomass (MJ) & 0.00 & 0.00 & 0.00 & 0.00 \\
\hline Renewable, biomass (MJ) & 0.02 & 0.01 & 0.53 & 0.40 \\
\hline $\begin{array}{l}\text { Renewable, wind, solar, } \\
\text { geothermal (MJ) }\end{array}$ & 0.12 & 0.05 & 2.62 & 1.40 \\
\hline Renewable, water (MJ) & 1.11 & 0.35 & 24.53 & 10.43 \\
\hline
\end{tabular}




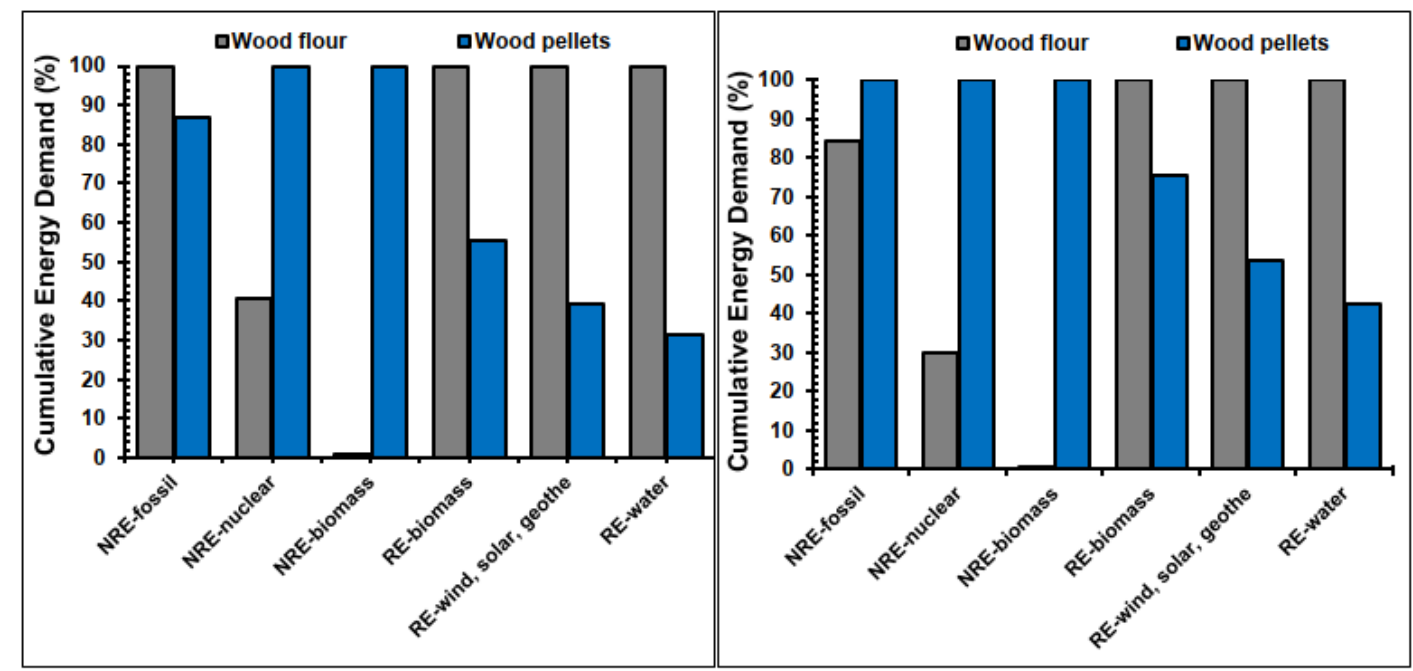

(a)

(b)

Figure 8 Comparative CED diagram for wood flour and pellets as functional unit of (a) one tonne and (b) one truckload.

The production of one tonne of wood flour or pellets consumes the highest amount of REs i.e., biomass, water, wind, solar, and geothermal but with differences in the percentage of total energy consumption. Renewable biomass, water, wind, solar, and geothermal energy were only depleted by plastic bags to the most and then the lubricants for each feedstock. However, wood products typically the woody biomass consumes more RE sources than NRE sources [70]. A lot of bioenergy was consumed during the biomass feedstock drying process, and most non-renewable fossil-based energy was consumed in the manufacturing of poly-lactic acid (PLA) based WPCs [71]. Fossil-based NRE use was primarily from the plastic bags followed by transportation and hardwood sawdust for wood flour, whereas for pellets was mainly from transportation and hardwood sawdust. The fossilbased energy was depleted by all the materials, fuels, electricity, transport, and ancillary inputs for both the wood feedstocks. NREs being consumed more by the materials i.e., wood residues could be attributable to the electricity usage beyond the pellet plant.

Production and transportation of one tonne of wood flour consumed more REs and NREs than the same unit of wood pellets except the non-renewable nuclear energy. A similar situation holds for one truckload functional unit but with a lower percentage of difference, except the fossil energy was consumed to a greater extent by the wood flour than the pellets. The percentage of differences in the cumulative energy demand for one tonne of the feedstocks from different sources are: NREfossil by $13 \%$, NRE-nuclear by $59 \%$, NRE-biomass by $99 \%$, RE-biomass by $45 \%$, RE-wind, solar, geothermal by $61 \%$, and RE-water by $69 \%$. Comparably, the percentage of differences in the CED for one truckload of the feedstocks from different energy sources are: NRE-fossil by $16 \%$, NREnuclear by $70 \%$, RE-biomass by $24 \%$, RE-wind, solar, geothermal by $46 \%$, and RE-water by $58 \%$. For NRE-biomass, even though the difference observed is $99 \%$, the value for either of the feedstocks is 0.00 and these very small numbers may be generated attributable to the noise, not true values. The major difference between the one tonne and one truckload of the feedstocks is the consumption of nuclear and water sources. Even though the percentage of differences for non-renewable fossils consumption appears small, the actual values in $\mathrm{MJ}$ are the highest compared to the other energy 
sources. Nejad et al. [62] pointed out that the difference in the amount of fossil energy usage was caused by variation in electricity usage between coal and natural gas to generate heat and power for the palletization of Napier grass-based feedstock. Differences in the consumption of plastic bags, electrical energy, and lubricating oil/grease are the direct major factors in this study. Composites made from natural fibers on average can reduce energy consumption by $60 \%$ per ton compared to glass fiber composites according to Pervaiz and Sain [72]. This study also showed the production and shipping of one truckload of wood flour consumed lesser NRE sources and more RE sources compared to the one truckload of wood pellets.

\section{Conclusions}

- For both wood feedstocks, the greatest impact to the environment was from transportation followed by the wood residues from hardwoods processing.

- The impact of electricity in the pellet plant was not essential as it uses biomass generated electricity.

- All the impact categories for production and transportation of one tonne of wood flour were higher than wood pellets except smog and ozone depletion. For one truckload of wood flour (22 tonnes) and pellets (30 tonnes), the impact from one truck load of pellets is higher than flour with a difference ranging from $12-30 \%$. However, after normalization of one truckload of the feedstocks, the impacts were similar for either feedstock.

- GWP is the major topic of interest at present. For one tonne production and transportation, GWP from wood flour is higher than from wood pellets by $11.13 \mathrm{~kg} \mathrm{CO}{ }_{2} \mathrm{eq}$ ( $8 \%$ more).

- For the same quantity of materials, the production and shipping via a truck appear to be more environmentally and economically friendly for wood pellets than the wood flour in this study.

- The findings of this study can be applied to the WPCs industry to encourage the utilization of wood pellets feedstocks to attain economic and environmental benefits.

\section{Acknowledgments}

The authors would like to acknowledge United States Forest Products Laboratory and School of Forest Resources, University of Maine for the technical support to conduct this research work.

\section{Author Contributions}

Geeta Pokhrel - Conceptualization, data collection, data analysis, software use, manuscript preparation; Hongmei Gu - Data analysis, visualization, supervision, manuscript review; Douglas J. Gardner - Conceptualization, data analysis, supervision, funding acquisition, resources, manuscript review; Shane O’Neill - Data collection, data analysis, resources, manuscript review.

\section{Funding}

This work was financially supported by United States Department of Agriculture (USDA) Agriculture Research Service (ARS) with Agreement Number/FAIN: 58-0204-9-166 and Project Number: 0204-41510-001-90S. 


\section{Competing Interests}

The authors have declared that no competing interests exist.

\section{References}

1. U.S. Energy Information Administration. Annual energy outlook 2021 [Internet]. Washington: U.S. Energy Information Administration; 2021. Available from: https://www.eia.gov/outlooks/aeo/.

2. Oliver A, Khanna M. What is the cost of a renewable energy-based approach to greenhouse gas mitigation? Land Econ. 2017; 93: 437-458.

3. Mantau U, Saal U, Prins K, Steierer F, Lindner M, Verkerk $H$, et al. Real potential for changes in growth and use of EU forests. Final report. Hamburg: EUwood; 2010; No. TREN/D2/491-2008.

4. Sommerhuber PF, Wenker JL, Rüter S, Krause A. Life cycle assessment of wood-plastic composites: Analysing alternative materials and identifying an environmental sound end-of-life option. Resour Conserv Recycl. 2017; 117: 235-248.

5. European Commission. Roadmap to a resource efficient Europe COM (2011) 571 [Internet]. Brussels: European Commission; 2011. Available from: https://www.eea.europa.eu/policydocuments/com-2011-571-roadmap-to.

6. European Parliament. Report on resource efficiency. Moving towards a circular economy [Internet]. Brussels: European Parliament; 2015. Available from: https://eurlex.europa.eu/legal-content/EN/TXT/HTML/?uri=OJ:C:2017:399:FULL\&from=RO.

7. Federal Ministry for the Environment, Nature Conservation and Nuclear Safety. Deutsches ressourceneffizienzprogramm (ProgRess) II: Fortschrittsbericht 2012-2015 und fortschreibung 2016-2019. Version RA 10.08.2015 [Internet]. Bonn: Federal Ministry for the Environment, Nature Conservation and Nuclear Safety; 2015. Available from:

https://www.bmu.de/fileadmin/Daten_BMU/Download_PDF/Ressourceneffizienz/progress II broschuere de bf.pdf.

8. European Commission. Documents on the circular economy package [Internet]. Brussels: European Commission; 2018. Available from:

https://ec.europa.eu/commission/publications/documents-strategy-plastics-circulareconomy en.

9. Hunt RG, Sellers JD, Franklin WE. Resource and environmental profile analysis: A life cycle environmental assessment for products and procedures. Environ Impact Assess Rev. 1992; 12: 245-269.

10. Curran MA, Young S. Report from the EPA conference on streamlining LCA. Int J Life Cycle Assess. 1996; 1: 57-60.

11. Pant D, Singh A, Van Bogaert G, Gallego YA, Diels L, Vanbroekhoven K. An introduction to the life cycle assessment (LCA) of bioelectrochemical systems (BES) for sustainable energy and product generation: Relevance and key aspects. Renew Sust Energ Rev. 2011; 15: 1305-1313.

12. Chau CK, Leung TM, Ng WY. A review on life cycle assessment, life cycle energy assessment and life cycle carbon emissions assessment on buildings. Appl Energy. 2015; 143: 395-413.

13. Khoshnevisan B, Shafiei M, Rajaeifar MA, Tabatabaei M. Biogas and bioethanol production from pinewood pre-treated with steam explosion and $\mathrm{N}$-methylmorpholine- $\mathrm{N}$-oxide (NMMO): $\mathrm{A}$ comparative life cycle assessment approach. Energy. 2016; 114: 935-950. 
14. Singlitico A, Goggins J, Monaghan RF. The role of life cycle assessment in the sustainable transition to a decarbonised gas network through green gas production. Renew Sust Energ Rev. 2019; 99: 16-28.

15. Temizel-Sekeryan S, Wu F, Hicks AL. Life cycle assessment of struvite precipitation from anaerobically digested dairy manure: A Wisconsin perspective. Integr Environ Assess Manag. 2021; 17: 292-304.

16. Hollas CE, Bolsan AC, Chini A, Venturin B, Bonassa G, Cândido D, et al. Effects of swine manure storage time on solid-liquid separation and biogas production: A life-cycle assessment approach. Renew Sust Energ Rev. 2021; 150: 111472.

17. Xu X, Jayaraman K, Morin C, Pecqueux N. Life cycle assessment of wood-fibre-reinforced polypropylene composites. J Mater Process Technol. 2008; 198: 168-177.

18. Rajendran S, Scelsi L, Hodzic A, Soutis C, Al-Maadeed MA. Environmental impact assessment of composites containing recycled plastics. Resour Conserv Recycl. 2012; 60: 131-139.

19. International Organization for Standardization. Environmental management-life cycle assessment-principles and framework. Geneva: International Organization for Standardization; 2006; ISO 14040.

20. International Organization for Standardization. Environmental management-life cycle assessment-requirements and guidelines. Geneva: International Organization for Standardization; 2006; ISO 14044.

21. Baumann H, Boons F, Bragd A. Mapping the green product development field: Engineering, policy and business perspectives. J Clean Prod. 2002; 10: 409-425.

22. Correia JR, Almeida NM, Figueira JR. Recycling of FRP composites: Reusing fine GFRP waste in concrete mixtures. J Clean Prod. 2011; 19: 1745-1753.

23. Scharnhorst W, Althaus HJ, Classen M, Jolliet O, Hilty LM. The end of life treatment of second generation mobile phone networks: Strategies to reduce the environmental impact. Environ Impact Assess Rev. 2005; 25: 540-566.

24. Alves C, Silva AJ, Reis LG, Freitas M, Rodrigues LB, Alves DE. Ecodesign of automotive components making use of natural jute fiber composites. J Clean Prod. 2010; 18: 313-327.

25. Baas LW, Boons FA. An industrial ecology project in practice: Exploring the boundaries of decision-making levels in regional industrial systems. J Clean Prod. 2004; 12: 1073-1085.

26. World Wide Fund for Nature. Mapping study on cascading use of wood products [Internet]. Gland: World Wide Fund for Nature; 2016. Available from: http://awsassets.panda.org/downloads/cascading use of wood web.pdf.

27. Bolin CA, Smith S. Life cycle assessment of ACQ-treated lumber with comparison to wood plastic composite decking. J Clean Prod. 2011; 19: 620-629.

28. Sun $G$, Ibach RE, Faillace M, Gnatowski M, Glaeser JA, Haight J. Laboratory and exterior decay of wood-plastic composite boards: Voids analysis and computed tomography. Wood Mater Sci Eng. 2017; 12: 263-278.

29. Ashori A. Municipal solid waste as a source of lignocellulosic fiber and plastic for composite industries. Polym Plast Technol Eng. 2008; 47: 741-744.

30. Teuber L, Osburg VS, Toporowski W, Militz H, Krause A. Wood polymer composites and their contribution to cascading utilisation. J Clean Prod. 2016; 110: 9-15. 
31. Wellness Recovery Action Plan. Plastics market situation report (springer 2016) [Internet]. Sudbury: Advocates for Human Potential, Inc.; 2016. Available from:

https://www.yumpu.com/en/document/read/55337132/plastics-market-situation-report.

32. Thompson DW, Hansen EN, Knowles C, Muszynski L. Opportunities for wood plastic composite products in the US highway construction sector. Bioresources. 2010; 5: 1336-1352.

33. Witik RA, Payet J, Michaud V, Ludwig C, Månson JA. Assessing the life cycle costs and environmental performance of lightweight materials in automobile applications. Compos Part A Appl Sci Manuf. 2011; 42: 1694-1709.

34. Liikanen M, Grönman K, Deviatkin I, Havukainen J, Hyvärinen M, Kärki T, et al. Construction and demolition waste as a raw material for wood polymer composites-assessment of environmental impacts. J Clean Prod. 2019; 225: 716-727.

35. Sommerhuber PF, Welling J, Krause A. Substitution potentials of recycled HDPE and wood particles from post-consumer packaging waste in wood-plastic composites. Waste Manag. 2015; 46: 76-85.

36. Väntsi $O$, Kärki T. Environmental assessment of recycled mineral wool and polypropylene utilized in wood polymer composites. Resour Conserv Recycl. 2015; 104: 38-48.

37. Pokhrel G, Gardner DJ, Han Y. Properties of wood-plastic composites manufactured from two different wood feedstocks: Wood flour and wood pellets. Polymers. 2021; 13: 2769.

38. Pokhrel G, Han Y, Gardner DJ. Comparative study of the properties of wood flour and wood pellets manufactured from secondary processing mill residues. Polymers. 2021; 13: 2487.

39. Pokhrel G, Kizha AR, Gardner DJ. Transportation cost analysis on alternative wood feedstocks for manufacturing wood-plastic composites. Bioresources. 2022; 17: 634-651.

40. Khan M, Hussain M, Deviatkin I, Havukainen J, Horttanainen M. Environmental impacts of wooden, plastic, and wood-polymer composite pallet: A life cycle assessment approach. Int J Life Cycle Assess. 2021; 26: 1607-1622.

41. Lestari R, Kamandanu FA, Prayitno H. Global potential market of forest biomass wood pellets. Adv Soc Sci Educ Humanit Res. 2022; 628: 332-338.

42. Bioenergy International. Wood pellets a "reliable and affordable" solution for EU's decarbonization [Internet]. Stockholm: Bioenergy International; 2021. Available from: https://bioenergyinternational.com/opinion-commentary/wood-pellets-a-reliable-andaffordable-solution-for-eus-decarbonization.

43. Production of EPAL pallets at a high level in 2019 again [Internet]. Düsseldorf: European Pallet Association; 2020. Available from: https://ee.epal-pallets.org/news/details/article/productionof-epal-pallets-at-a-high-level-in-2019-again.

44. Leblanc R. What is a pallet? Introduction to pallets [Internet]. Ottawa: Reusable Packaging News; 2020. Available from: https://packagingrevolution.net/pallets-introduction-to-pallet-usage/.

45. Koči V. Comparisons of environmental impacts between wood and plastic transport pallets. Sci Total Environ. 2019; 686: 514-528.

46. Maine Woodland Owners. 2017 Directory of Maine's stationary and portable sawmills [Internet]. Augusta: Maine Woodland Owners; 2017. Available from:

https://static1.squarespace.com/static/5da9047aa7b835389a38c978/t/5dd6f5690ab5465cb2 0418ed/1574368620425/Online Portable Sawmills 2018.pdf.

47. Innovative Natural Resource Solutions LLC, Meister Consultants Group, A Cadmus Company. Forest opportunity roadmap/Maine wood energy. Boston: Innovative Natural Resource 
Solutions LLC and Meister Consultants Group, A Cadmus Company; 2018. Available from: http://formaine.org/wp-content/uploads/2020/09/FOR-Maine-Wood-Energy-final-9-2018.pdf.

48. Global market analysis and benchmarking study. Phase 1: Global market analysis. Final report. Washington, DC: Indufor North America LLC.; 2018; A1811451.

49. O’Neill S. Conversation with: Julie Linkletter. Athens: Maine Wood Pellets Co.; 2021.

50. Magelli F, Boucher K, Bi HT, Melin S, Bonoli A. An environmental impact assessment of exported wood pellets from Canada to Europe. Biomass Bioenergy. 2009; 33: 434-441.

51. Yu J, Chen LX. The greenhouse gas emissions and fossil energy requirement of bioplastics from cradle to gate of a biomass refinery. Environ Sci Technol. 2008; 42: 6961-6966.

52. Magelli F, Bi HT. A streamlined life cycle analysis of Canadian wood pellets. Proceedings of International Conference on Life Cycle Assessment and Management 2007-from Measurement to Investment; 2007 October 2nd-4th; Portland, OR, USA. New York: Curran Associates, Inc.

53. Vink ET, Glassner DA, Kolstad JJ, Wooley RJ, O'Connor RP. The eco-profiles for current and nearfuture NatureWorks ${ }^{\circledR}$ polylactide (PLA) production. Ind Biotechnol. 2007; 3: 58-81.

54. Bare J. TRACI 2.0: The tool for the reduction and assessment of chemical and other environmental impacts 2.0. Clean Technol Environ Policy. 2011; 13: 687-696.

55. Ryberg M, Vieira MD, Zgola M, Bare J, Rosenbaum RK. Updated US and Canadian normalization factors for TRACI 2.1. Clean Technol Environ Policy. 2014; 16: 329-339.

56. Hagberg L, Saernholm E, Gode J, Ekvall T, Rydberg T. LCA calculations on Swedish wood pellet production chains. Stockholm: The Swedish Environmental Research Institute Ltd.; 2009; IVL-B1873.

57. Reed D, Bergman R, Kim JW, Taylor A, Harper D, Jones D, et al. Cradle-to-gate life-cycle inventory and impact assessment of wood fuel pellet manufacturing from hardwood flooring residues in the southeastern United States. For Prod J. 2012; 62: 280-288.

58. IQS Directory. Polyethylene bags VS polypropylene bags [Internet]. Grand Rapids: IQS Directory. Available from: https://blog.iqsdirectory.com/polyethylene-bags-2/.

59. Bergman RD, Bowe SA. Environmental impact of manufacturing softwood lumber in northeastern and north central United States. Wood Fiber Sci. 2010; 42: 67-78.

60. Milota MR, West CD, Hartley ID. Gate-to-gate life-cycle inventory of softwood lumber production. Wood Fiber Sci. 2005; 37: 47-57.

61. Bergman RD. Environmental impact of producing hardwood lumber using life-cycle inventory. Wood Fiber Sci. 2008; 40: 448-458.

62. Manouchehrinejad M, Sahoo K, Kaliyan N, Singh H, Mani S. Economic and environmental impact assessments of a stand-alone napier grass-fired combined heat and power generation system in the southeastern US. Int J Life Cycle Assess. 2020; 25: 89-104.

63. Alanya-Rosenbaum S, Bergman RD. Life-cycle impact and exergy based resource use assessment of torrefied and non-torrefied briquette use for heat and electricity generation. J Clean Prod. 2019; 233: 918-931.

64. Alanya-Rosenbaum S, Bergman RD, Gething B. Assessing the life-cycle environmental impacts of the wood pallet sector in the United States. J Clean Prod. 2021; 320: 128726.

65. Wu T, Gong M, Xiao J. Preliminary sensitivity study on an life cycle assessment (LCA) tool via assessing a hybrid timber building. J Bioresources Bioprod. 2020; 5: 108-113.

66. Arshadi M, Gref R. Emission of volatile organic compounds from softwood pellets during storage. For Prod J. 2005; 55: 132-135. 
67. Muise I, Adams M, Côté R, Price GW. Attitudes to the recovery and recycling of agricultural plastics waste: A case study of Nova Scotia, Canada. Resour Conserv Recycl. 2016; 109: 137-145.

68. Orecchio S, Amorello D, Barreca S. Wood pellets for home heating can be considered environmentally friendly fuels? Heavy metals determination by inductively coupled plasmaoptical emission spectrometry (ICP-OES) in their ashes and the health risk assessment for the operators. Microchem J. 2016; 127: 178-183.

69. Sahoo K, Alanya-Rosenbaum S, Bergman R, Abbas D, Bilek EM. Environmental and economic assessment of portable systems: Production of wood-briquettes and torrefied-briquettes to generate heat and electricity. Fuels. 2021; 2: 345-366.

70. Bergman RD, Alanya-Rosenbaum S. Cradle-to-gate life-cycle assessment of laminated veneer lumber production in the United States. For Prod J. 2017; 67: 343-354.

71. Qiang T, Yu D, Zhang A, Gao H, Li Z, Liu Z, et al. Life cycle assessment on polylactide-based wood plastic composites toughened with polyhydroxyalkanoates. J Clean Prod. 2014; 66: 139-145.

72. Pervaiz $M$, Sain MM. Carbon storage potential in natural fiber composites. Resour Conserv Recycl. 2003; 39: 325-340.

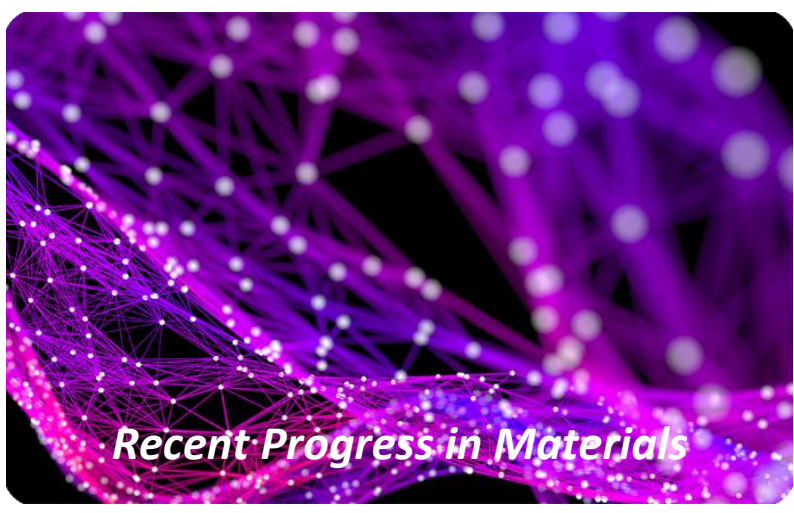

Enjoy Recent Progress in Materials by:

1. Submitting a manuscript

2. Joining in volunteer reviewer bank

3. Joining Editorial Board

4. Guest editing a special issue

For more details, please visit: http://www.lidsen.com/journals/rpm 